

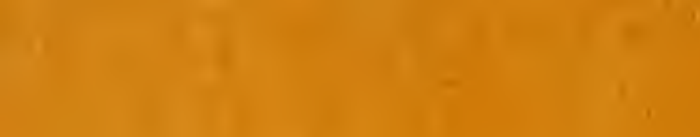

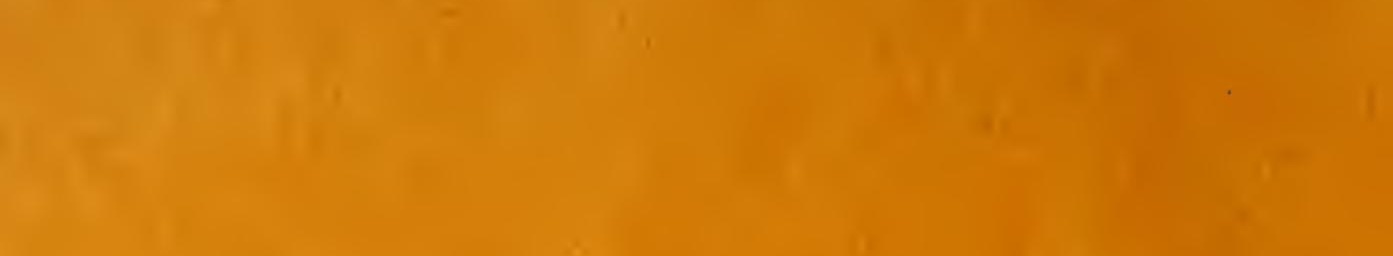

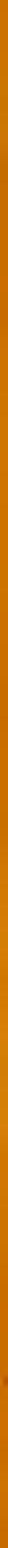

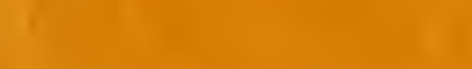

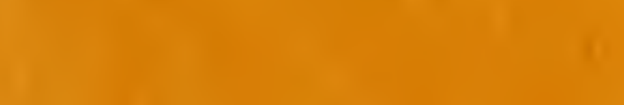

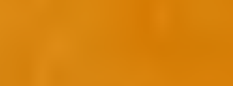

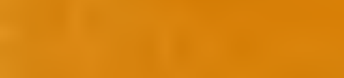

atian

1

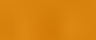




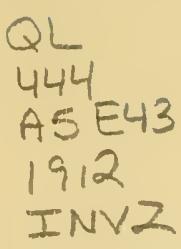

[Contributions from the Limnological Laboratory of Cornell University Ithaca, N. Y.]

\title{
A Preliminary Study of the Distribution, Food and reproductive Capacity of some fresh-water Amphipods.
}

\author{
By \\ George C. Embody. \\ With 1 plate and 5 Text-figures.
}

\section{Contents.}

I. Introduction. - II. Relative sizes of forms studied. - III. Distribution about Ithaca, New York. - IV. Food. - V. Reproduction: 1. Period. 2. Mating: a) Method; b) Duration. 3. Oviposition and Fertilization. 4. Number of eggs. 5. Period of Incubation. 6. Young: Activities and Relation to Parent. 7. Recurrence of the Reproductive Activities. - VI. Moulting of Adults. - VII. Moulting of Young. - VIII. Method of Moulting. - IX. Growth. - X. The Progeny from a Single Pair in one Year. XI. Enemies. - XII. Summary. - Bibliography.

\section{Introduction.}

The present paper deals with the activities of four locally common species of amphipods representing two different families and three genera, namely:

I. Family, Gammaridae

1. Gammarus fasciatus Say.

2. Gammarus limnaeus Smith.

3. Eucrangonyx gracilis (Smith).

II. Family, Orchestiidae

4. Hyalella knickerbockeri (Bate).

With the exception of one blind species these are the only amphipoda known to occur in the vacinity of Ithaca.

The observations were made upon individuals in their own native environments and likewise upon others placed in balanced aquaria furnished with characteristic vegetation and from which all natural enemies had been eliminated. The investigation was begun with the ultimate purpose of securing sufficient data to show the practicability 
or the impracticability of propagating amphipods as food for fishes and in case of the former to determine which species would lend themselves most readily to such a procedure. During the progress of this study a few supposedly new facts came to light which had no apparent relation with the original problem. It is believed however that these are of sufficient importance to other lines of investigation to justify their inclusion here.

I desire to express my gratitude to Dr. J. G. Needham of Cornell University, under whose helpful guidance this investigation was carried on. His constant sympathy with the work and his generous and kindly criticism contributed largely to its successful completion.

\section{Relative sizes of the forms studied.}

The maximum sizes attained by adults of the four species in the water examined are contrasted on plates I and II, and likewise in table $\mathrm{I}^{1}$ ). It will be noticed that $\mathrm{G}$. limnaeus is larger than the other three; G. fasciatus ranking second; E. gracilis, third and Hyalella being the smallest.

Table I. Lengths of largest adults collected.

\begin{tabular}{c|c|c|c|c}
\hline Species & G. limnaeus & G. fasciatus & E. gracilis & Hyalella \\
\hline \hline Length in $\mathrm{mm}$ & 22,42 & 15,3 & 11,47 & 7,4
\end{tabular}

Miss Weckel states (1907 p. 33) that adults of E. gracilis vary in length from 7 to $18 \mathrm{~mm}$. At Ashland, Va., the writer found them as long as $13 \mathrm{~mm}$, and at Irvington, Ind., in pools not inhabited by fish individuals as long as $15 \mathrm{~mm}$ were common. The writer is unable to account for the small size attained by those in waters at Ithaca, unless it be from the fact (Table XI, p. 23) that these amphipods grow much less rapidly than the other three forms and also that fishes and other enemies are abundant enough to devour them before the maximum size is reached.

\section{Distribution about Ithaca, New York.}

G. fasciatus so far as known is confined to Cayuga Lake and its immediate tributaries. Its distribution in these waters varies with the season. In March just after the disappearance of ice, it may be pag. 25.

$\left.{ }^{2}\right)$ The lengths of the smallest sexually mature females are given in table XII, 
found in small numbers along the lake margin and in the mouths of the tributaries wherever vegetation exists. It is very scarce at a distance of eight or ten rods away from the lake. As the season advances, its distribution is extended so that by the first part of August, it is exceedingly abundant throughout the cove and the adjoining propagating ponds of the Biological Field Station; in the Fall Creek to the beginning of rapid water, a distance slightly greater than oneeighth of a mile from the lake, and up the Cayuga Lake Inlet to a point approximately one-fourth of a mile distant from the lake. From this time until after the ice appears it is the most abundant amphipod wherever found.

It seems to occur in greatest abundance where vegetation is thickest and is associated with thick masses of Marsilea, Elodea, Potamogeton, Myriophyllum and Utricularia. That it occurs abundantly in certain parts of the Montezuma Marshes at the north end of Cayuga Lake, is indicated by the presence of seventy-two individuals in the enteron of a king eider duck taken there November 26, 1909 (Embody, 1910). Warm water does not seem to bar its distribution since it occurs and breeds in the waters of the "Cove" where the temperature becomes as high as $30^{\circ} \mathrm{C}$. This species does not occur in the isolated pools of Renwick Marsh and I am unable to account for its absence unless the drought of summer and the frost of winter kill off those which may have entered during floods. before they have had a chance to multiply sufficiently to be detected.

The writer has not yet been able to locate individuals of Gammarus limnaeus in Ithaca waters. It in stated that the New York Forest, Fish, and Game Commission (Report for 1897) placed five thousand from Caledonia Creek into the waters of Six-mile Creek above Ithaca in 1896, that these might propagate and furnish food for brook trout.

The species occurs very abundantly in a trout brook near Auburu, N. Y. and at this place the writer was able to gather a few notes upon its distribution. It seems to occur in greatest numbers near the head-waters of the brook and its tributaries, and even in the springs themselves ${ }^{1}$ ). The largest numbers were found associated with the roots of the water cress, thick tangles of Chara and under decaying leaves. No individuals were found in pools well down the brook where

1) The yearly range of temperature in the upper part of this brook is from $6^{\circ}-12^{\circ} \mathrm{C}$. 
the water gave a temperature above $16^{\circ} \mathrm{C}$. They were equally abundant in rapid and quiet water; in fact, in any place where there was sufficient accumulation of Chara, water cresses and dead leaves, and where the water was suffiently cool.

Hyalella knickerbockeri and Eucrangonyx gracilis are not so limited in distribution as the foregoing forms. Both are found in the cold waters of the trout brook and in the warmest waters of Renwick Marsh. They occur in Cayuga Lake, and in Fall Creek and the Inlet above and below the falls wherever there is an accumulation of living or dead vegetation. In spite of the drying up of the marsh, the burning of the cattails and sedges and the freezing of the ground to a depth of from six to ten inches, both amphipods appear each spring in the usual large numbers in various marsh pools.

\section{Food.}

So far as could be determined the food taken by individuals of the four species did not differ in quality. That which was offered to aquarium specimens, if accepted or refused by one was treated in exactly the same manner by members of the other three species. In general amphipods feed largely upon plants either living or dead and upon carcasses of animals in which putrefaction has not progressed too far. Dead leaves and plant stalks are readily stripped of their softer tissues and these constituted the larger portion of the food of the amphipods under observation.

One large female G. fasciatus living in a small aquarium was observed repeatedly pulling of a dying leaf of an aquatic moss and later swimming about the aquarium carrying it until the leaf had been eaten. In this case there was a deliberate selection of one dying leaf from a multitude of living ones.

On the sides of a few of the aquaria there appeared large growths of the alga, Coleochaete. The smaller amphipods discovered these very soon after they had appeared and immediately began to eat out the central cells. It was not uncommon to see seven or eight amphipods in each aquarium perched upon as many different plants greedily eating away the cells. Eventually the animals cleaned the sides of the aquaria nearly as effectively as might have been done by snails.

Among the aquatic plants largely eaten by amphipods, the following were noticed: The epidermis of leaves and stems of Elodea, Myriophyllum, Utricularia, Chara, Sphagnum and Lemna; the 
rhizoids of Ricciocarpus, and the filaments of Chaetophora, Spirogyra and certain blue-green algae.

In early spring the amphipods Hyalella and Eucrangonyx often congregate in large numbers in the prolific masses of Spirogyra. In cases which came under observation, it was noticed that the animals seemed to prefer dead bits of leaves and other plant remains which occured in these masses, in place of the green algal filaments.

Animal tissue constitutes not an unimportant element in the diet of amphipods. Freshly killed isopods, snails, earthworms, tadpoles and bits of tissue from fish, and of beef were greedily taken by young as well as by adults. A freshly killed amphipod is readily devoured by its fellows.

Individuals of any one of the four species will viciously attack a wounded Asellus. If one of the latter is slightly cut or torn the exuding juices attract these Crustaceans in great numbers. They pounce upon the wounded spot and in a short time tear the softer parts of the body into shreads. Each amphipod pulls off a piece and swims away with it. Even the whole carcass may be carried away by an especially large one. The gnathopods and maxillipeds ordinarily are used for holding the food but in tearing off shreads of tissue or in pulling one piece away from another amphipod, the use of the mandibles in opposition to the gnathopods seems to be necessary for success. Banta states (1907 p. 78) that in Mayfield's Cave, Indiana, Eucrangonyx gracilis "sometimes feeds upon the cave isopod, Caecidotea stygia. I have twice seen it in an aquarium catch a living Caecidotea. It feeds upon any organic matter or even upon the carcass of a fellow".

Several freshly crushed planaria were at different times offered to individuals of each of the four species of amphipods but in every case were refused. Whenever an amphipod came within the region poluted by the body fluids of a planarian the former would instantly jump away, indicating a disagreeable irritating property of the fluid.

In July 1908, a sora rail which had been dead a day or two was found floating in a marsh pool. Its feathers were alive with Hyalellas which had been feeding upon the decomposing flesh.

It has been stated that the cast off skins are sometimes devoured and that these amphipods even prey upon one another. Those under observation were frequently seen tearing to pieces their cast skins but in no case was there convincing evidence that any portion of the latter had been eaten. Only indirect evidence came to my notice tending to 
show that one amphipod will kill and devour its neighbor. In certain aquaria where pairs had been isolatod, the female mysteriously disappeared, usually immediately after moulting. In one aquarium two different females disappeared in one week, only the exoskeletons being left. A third female was admitted and a day later the male moulted and died. The female continued to live in this same aquarium through five different moults.

\section{Reproduction.}

1. Period.

Collections representing the three species, Hyalella knickerbockori, Eucrangonyx gracilis and Gammarus fasciatus, were taken from Ithaca waters almost weekly from October, 1908, until August, 1910, except during the colder periods of winter when Cayuga Lake and tributaries were frozen. Individuals of Gammarus limnaeus and also E. gracilis were collected from a trout brook near Auburn, New York upon the following dates: Jan. 8 and 22. April 5, July 10, 1909; Jan. 22 and Sept. 10, 1910.

In the following table II, are given the earliest and latest dates upon which the various species were found breeding, together with the approximate length of the total reproductive period of each spe$\operatorname{cies}^{1}$ ).

Table II.

\begin{tabular}{|c|c|c|c|}
\hline Species & Earliest Date & Latest Date & Period \\
\hline $\begin{array}{l}\text { G. limnaeus } \\
\text { G. fasciatus } \\
\text { E. gracilis } \\
\text { Hyalella }\end{array}$ & $\begin{array}{l}\left.\text { Jan. 8, 1909. young }{ }^{3}\right) \\
\text { April 18, 1910. eggs } \\
\text { Jan. 8, 1909. } \\
\text { April 2, } 1910 .\end{array}$ & $\begin{array}{l}\text { Sept. 10, } 1910 \text { eggs } \\
\text { Nov. 3, } 1909 \\
\text { Nov. 3, } 1909 \\
\text { Sept. 1, } 1909\end{array}$ & $\begin{array}{l}266 \text { days }^{3} \text { ) } \\
199 \text { " } \\
299 \quad \text { " }) \\
152 \quad n\end{array}$ \\
\hline
\end{tabular}

1) The reproductive period as given for the species must not be confused with that for the individual. The two may or may not be identical. That they are identical is indicated by the fact that in almost every collection the breeding females were in the majority over non-breeding ones. On the other hand the pairs under observation in balanced aquaria indicated that the individual's reproductive period was of comparatively short duration, for not.a single female produced more than three censecutive sets of eggs and these within a period not to exceed sixty days.

$\left.{ }^{2}\right)$ If the trout brook near Auburn, New York, were to be studied during the months of October, November and December, the reproductive periods of E. gracilis and G. limnaeus might be showed to be longer.

$\left.{ }^{8}\right)$ Since young were found in the brood pouches of many females on this date and since the period of incubation (p. 13) is 21 days or undoubtedly longer at lower temperatures, it is very probable that the reproductive period is twenty one days or more, longer than is indicated by the date here given; hence the approximate period is used as corrected from 245 to 266 days. 
Banta observes (1907) that in Mayfield's Cave, Indiana, E. gracilis appears to breed at all seasons, adults with the young in the brood pouch having been found throughout the year. No water temperatures are given but he indicates that the temperatures of the air in remote parts of the cave have a yearly range from about $8^{\circ}$ to $12^{\circ} \mathrm{C}$. In a spring fed pool along the Lehigh Valley R. R., tracks near Ithaca, N. Y., large numbers of E. gracilis were found breeding February 16, 1910. The temperature of the water was $8^{\circ} \mathrm{C}$ while that of the air was $-8^{\circ} \mathrm{C}$. Again in the previously mentioned trout brook near Auburn New York individuals of the same species were found breeding abundantly as early as January 8, 1909 and January 22, 1910. The temperatures of the water upon these dates were $6^{\circ}$ and $8^{\circ} \mathrm{C}$ respectively.

The last three species mentioned in Table II seem not to be affected in their breeding by compartively high temperatures. Mated pairs and females with eggs and young were found throughout the summer in certain marsh pools and lagoons near Ithaca, the temperature of which remained between $23^{\circ}$ and $30^{\circ} \mathrm{C}$ during a greater part of the period. When placed in balanced aquaria they continued to breed from early March until late August.

Gammarus limnaeus acted quite differently. Adult females with eggs when placed in balanced aquaria in July, died within a few days. Those so treated in January continued to breed in captivity until the fore part of March when the temperature of the aquaria approached $18^{\circ} \mathrm{C}$. These same females, however, continued to live and apparently feed normally until late in June.

In the following table III are recorded the highest and lowest water temperatures together with the average of some twenty-six readings taken during the reproductive period of each species. However, in the case of G. limnaeus it was not possible to take a large enough number of readings to deduce an average representing the true conditions. Consequently the temperature given in the table for the average is in reality the $\operatorname{mean}^{1}$ ).

Table III.

\begin{tabular}{l|c|c|c}
\hline Species & Minimum Temp. & Maximum Temp. & Average Temp. \\
\hline \hline G. limnaeus & $6^{\circ} \mathrm{C}$ & $12^{\circ} \mathrm{C}$ & $9^{\circ} \mathrm{C}$ \\
G. fasciatus & $11,1^{\circ} \mathrm{C}$ & $30^{\circ} \mathrm{C}$ & $17,9^{\circ} \mathrm{C}$ \\
E. gracilis & $6^{\circ} \mathrm{C}$ & $30^{\circ} \mathrm{C}$ & $17,16^{\circ} \mathrm{C}$ \\
Hyalella & $7,8^{\circ} \mathrm{C}$ & $30^{\circ} \mathrm{C}$ & $20,14^{\circ} \mathrm{C}$
\end{tabular}

1) It should be remembered that the brook where the observations upon $G$. limnaeus were made, is a cold spring trout brook and near its source only slightly 


\section{Mating.}

Prof. S. J. Holmes gives a very excellent account of the mating of Hyalella dentata. He concludes that as the sexual impulse appears, the males find the females accidentally; that neither sight nor the olfactory sense play any part in the process. Briefly stated, the male comes in contact with the female which immediately curls up the abdomen and remains impassive. The male grasps her with his gnathopods and after much jerking finally adjusts his companion to the proper position and swims about through the water bumping into various obstacles. Throughout the mated period the female remains unresisting, simply grasping whatever food may come within reach and constantly moving her pleopods to aerate the gills.

Miss Smallwood observed (1905) that in Orchestia palustris, the male hooks the dactylus of the large gnathopod under the anterior edge of the fourth or fifth coxal plate on either side, right claw used mostly. The bases of the peraeopods and the flexed abdomen assisted.
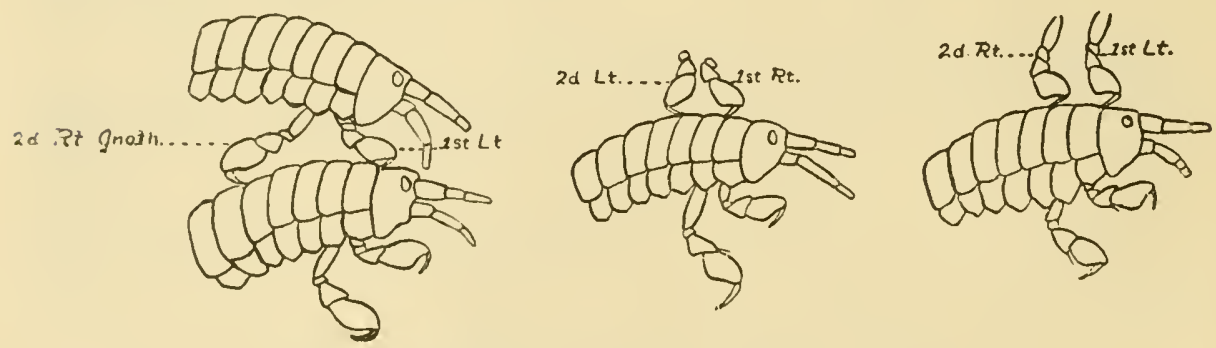

Fig. 1-3. Position of gnathopods during mating.

A number of mated individuals of Gammarus limnaeus were placed under observation during February and March, 1910. There was found to be some variation in the manner in which the males grasp the females. A very secure hold and one commonly used was as follows; dactylus of first left gnathopod hooked caudad into the suture between the head and the first dorsal plate, the dactylus of the second right gnathopod hooked cephalad between the fourth and fifth dorsal plates (fig. 1) the other gnathopods remaining free. The peraeopods and flexed abdomen may have assisted but their use seemed not to

influenced by the external heat. It is therefore quite safe to take the mean temperature as representing the average condition of the water during the reproductive period. 
have been required. A few variations in the use of the two gnathopods were noted and two of them are illustrated in figures 2 and 3. In a few cases all four gnathopods were used, doubly securing the union of two mated animals.

It is seen that in the cases represented by figures 1 and 2 the gnathopods were used in a manner similar to that of a pair of tongs, thereby uniting the mated pair so strongly that is was impossible to separate them without injury to one or both.

\section{b) Duration of Mating.}

Since mating is a one sided affair for which the male is almost solely responsible, it is evident that the physiological condition of the male determines at what time mating takes place. When does the sexual desire appear in the male and how long may it persist if not satisfied by copulation, are questions upon which the writer can throw only dim light. The observations taken indicate that if the sexual impulse appears between any two moults, it may likewise assert itself between the second and third succeeding moults but whether it may occur between every two, is not known.

A male may exhibit the sexual impulse for a number of days during the period between moults. In the case of G. limnaeus when the period between moults is 36 days, in water having a mean daily temperature of $17,3^{\circ} \mathrm{C}$, the impulse may appear as early as the sixteenth, day and may persist until the twenty-seventh day. The possible range is thus $12^{1}$ ) days. With Hyalella when the period between moults is 28 days at a mean daily temperature of $23,2^{\circ} \mathrm{C}$, it may appear at the seventh day and may persist until the twenty-fifth day, a possible range of 18 days.

The writer was unable to secure complete data with reference to the other two species under consideration but one male G. faciatus was observed to copulate successfully four days before moulting.

Once mated the pair remain together until the female moults. Then they usually separate for a brief period. ${ }^{2}$ ) The male seems to lose his

1) This range may be greater. The cases given represent the earliest and latest times of mating which resulted in copulation and subsequent appearance of fertilized eggs.

2) This period varies from a few minutes to several hours. One Hyalella thus remained separated from his mate from about $9 \mathrm{~A}$. M., until 4 P. M., of the same day. In the case of G. fasciatus, one male grasped the female throughout the moulting period. As the old skin split transversely along the suture between 
hold during the ecdysis of the female but regains it soon after the female has emerged. The pair continue together until copulation has taken place. After this act, in all cases which came to my notice, the inale separated from the female permanently or at least until he had moulted once.

Miss Clara Langenbeck (1898, p. 305) found practically the same state of affairs obtaining among amphipods of the genus, Microdeutopus. According to her observations the male's second separation from the female occurred shortly before the extrusion of the eggs.

Dr. S. J. Holmes states $(1903$, p. 288) with reference to the observations of A. Della Valle on Gammarus pungens that after the act of copulation, the male regains his original position and swims about with the female as before.

Frequent captures of mated females of the three species, G. fasciatus, G. limnaeus and Hyalella with pouches full of eggs or young led the writer at first to believe that the males remained with the females for a number of days after oviposition and even after the eggs had hatched. In every case tested however, it was found that the male was to become father of the next succeeding brood; and furthermore, inability to secure two successive matings of the same male during the period between two moults convinced me that these males were not responsible for the eggs or young present in the pouches at the time of collection.

\section{Oviposition and Fertilization.}

Oviposition and fertilization have been observed by A. Della Valle for Gammarus pulex (1889) and for Microdeutopus gryllotalpa by Miss Langenbeck (1898, p. 305). According to the observations of the former as abstracted in the "Zoological Record", the oviducts have ordinarily no external apertures. Oviposition is preceded by a casting of the integument whereby external openings are temporarily formed. Fertilization is quite external, no intromittent organs being employed. The sperm is ejected upon the ventral surface of the female round the terminations of the oviducts. The eggs issue simultaneously by the two oviducts, and are accompained by a viscid substance which plugs

the head and the first dorsal plate, the male placed one gnathopod through the slit and inserted the dactylus in the usual place on the female. In this manner his hold was retained with difficulty until the female emerged free, when the usual firm hold was obtained. 
the orifices. The eggs are at first without any trace of chorion which, however appears after fecundation.

Miss Langenbeck observed practically the same method for Microdeutopus. One female however, whose eggs were just in condition to be extruded, was isolated before it had moulted. After a time this one "sloughed" and the eggs were extruded in the normal way but apparently without copulation with the male. It is stated that these eggs did not segment.

I was unable to find a female of any species which would deposit eggs without the influence of the male. One female Gammarus limnaeus whose unlaid eggs constituted two conspicuous black masses in the ovaries, was isolated. This one moulted early the following morning, but failed to deposit its eggs during the next twenty-four hours. At the end of this period a breeding male was admitted and immediately clasped the female. Three hours later the marsupial pouch of the latter contained twenty-five eggs which in due time developed normally into as many young amphipods.

In table IV are given the results of egg counts for the four species In every case animals of various sizes from the smallest mature female to the largest were separately killed, the eggs carefully removed from the brood pouches and counted.

It can be seen that the number of eggs varies with, (a) the species, (b) the size or age of the individual, (c) with the individual irrespective of size. The average number of eggs produced at one time by an individual of G. limnaeus is about 25; of G. faciatus, 22; of E. gracilis, 45; of Hyalella, 18 . In general we find a larger average number produced by the older individuals although the individual variation irrespective of size is so great as to prohibit the deduction of any definite ratio. The great variation among individuals of the same species of approximately the same size may be partially accounted for by the loss of eggs due to imperfect fertilization or to accidents to the female. Both cases were observed in the aquaria specimens but it is not known to what extent this takes place in a natural environment.

\section{Period of Incubation.}

In order to determine the amount of time required for the complete development of the eggs, it was necessary to capture mated pairs before oviposition had taken place and to isolate them in small dishes supplied with aquatic plants. A maximum-minimum thermometer was suspended near the dishes and readings taken daily. It was observed, 
Table IV. Egg Counts.

\begin{tabular}{|c|c|c|c|c|c|c|c|c|c|c|c|}
\hline \multicolumn{3}{|c|}{ G. $\operatorname{limnaeus}$} & \multicolumn{3}{|c|}{ G. fasciatus } & \multicolumn{3}{|c|}{ E. gracilis } & \multicolumn{3}{|c|}{ Hyalella } \\
\hline Date & 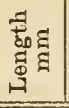 & 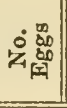 & Date & 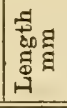 & 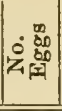 & Date & 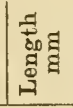 & 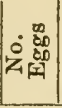 & Date & 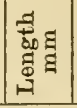 & 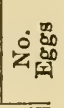 \\
\hline 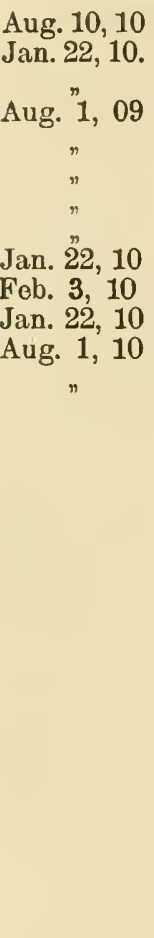 & $\begin{array}{l}9 \\
11,5 \\
12 \\
12,5 \\
13 \\
14 \\
14 \\
14 \\
14 \\
14 \\
14,2 \\
15,5 \\
16\end{array}$ & $\begin{array}{r}8 \\
10 \\
15 \\
24 \\
28 \\
33 \\
32 \\
38 \\
27 \\
25 \\
26 \\
10 \\
40\end{array}$ & $\begin{array}{l}\text { Aug. 8, } 10 \\
\text { Aug. "5, } 10 \\
\text { " } \\
\text { " } \\
\text { " } \\
\text { Oct. 6, } 09 \\
\text { Aug. } 5,10 \\
\text { Aug. 9, } 10 \\
\text { Oct. "6, } 09 \\
\text { Apr. } 21,10\end{array}$ & $\begin{array}{r}5,8 \\
6,1 \\
6,6 \\
6,8 \\
7,1 \\
7,6 \\
8,2 \\
9,2 \\
9,2 \\
9,4 \\
9,6 \\
9,8 \\
10,7 \\
10,7 \\
10,9 \\
12\end{array}$ & $\begin{array}{r}6 \\
11 \\
13 \\
14 \\
20 \\
24 \\
20 \\
21 \\
27 \\
21 \\
18 \\
27 \\
31 \\
31 \\
26 \\
46\end{array}$ & 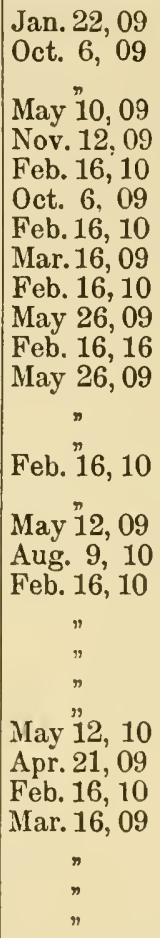 & $\begin{array}{r}5,6 \\
6,2 \\
6,6 \\
6,6 \\
6,6 \\
6,9 \\
7,1 \\
7,4 \\
7,6 \\
7,7 \\
7,7 \\
7,9 \\
8,2 \\
8,2 \\
8,2 \\
8,4 \\
8,4 \\
8,5 \\
8,7 \\
8,7 \\
8,7 \\
8,7 \\
8,7 \\
8,7 \\
8,7 \\
8,9 \\
8,9 \\
8,9 \\
8,9 \\
8,9 \\
10,5\end{array}$ & $\begin{array}{l}25 \\
26 \\
25 \\
24 \\
21 \\
26 \\
20 \\
40 \\
34 \\
37 \\
25 \\
45 \\
50 \\
52 \\
65 \\
56 \\
56 \\
69 \\
23 \\
38 \\
56 \\
27 \\
58 \\
55 \\
69 \\
93 \\
65 \\
52 \\
59 \\
57 \\
68\end{array}$ & $\begin{array}{c}\text { Aug. } 5,10 \\
" \\
" \\
" \\
" \\
" \\
" \\
" \\
" \\
" \\
" \\
\text { May } 12,09 \\
" \\
" \\
\text { Aug, } 5,10 \\
\text { May } 12,10 \\
" \\
\text { Aug. } 5,10 \\
" \\
"\end{array}$ & \begin{tabular}{|l|}
3,06 \\
3,3 \\
3,3 \\
3,6 \\
3,8 \\
4,3 \\
4,6 \\
4,8 \\
4,8 \\
4,8 \\
5,1 \\
5,1 \\
5,6 \\
5,6 \\
6,1 \\
6,1 \\
6,3 \\
6,4 \\
6,4 \\
6,4 \\
6,9 \\
6,9 \\
7,1 \\
7,1 \\
7,4 \\
7,4
\end{tabular} & $\begin{array}{r}6 \\
12 \\
9 \\
10 \\
22 \\
17 \\
19 \\
22 \\
19 \\
8 \\
11 \\
20 \\
23 \\
22\end{array}$ \\
\hline & & & & & & & Ave. & & & Ave. & \\
\hline
\end{tabular}

while the mean daily temperature of the water might be higher or lower than that of the air, that in the course of a number of days the average means in the two cases remained practically equal. Therefore in the determinations which are to follow, use has been made of the mean daily temperatures of the air as registered by the maximumminimum thermometer. Observations upon the progress of development of the eggs in the brood pouches were made daily, at first and towards the end of the incubation period, twice daily.

As an experiment some of the eggs of a fow females were taken from the brood pouches and placed in watch glasses, each glass having been supplied with water and plants (Lemna and Elodea) from the 
original dishes. It was observed that if these eggs were so treated within four or five days of the date of hatching they would continue to develop normally and hatch in approximately the some time as those that remained in the brood pouches.

Even though a great many trials were made only scanty data were forthcoming. A large number of failures were due to the untimely disappearance of the females within a few days after oviposition. This was finally overcome by separating the sexes as soon as possible after the appearance of eggs in the brood pouch. No male was caught in that act of killing its mate but the circumstantial evidence of murder was very strong.

Table V.

\begin{tabular}{|c|c|c|c|c|c|}
\hline Species & $\begin{array}{c}\text { Date } \\
\text { of Oviposition }\end{array}$ & $\begin{array}{c}\text { Date } \\
\text { of Hatching }\end{array}$ & $\begin{array}{c}\text { Period } \\
\text { in } \\
\text { days }\end{array}$ & $\begin{array}{l}\text { Sum } \\
\text { of mean } \\
\text { daily } \\
\text { temp. }\end{array}$ & $\begin{array}{l}\text { Ave. } \\
\text { mean } \\
\text { daily } \\
\text { temp. }\end{array}$ \\
\hline $\begin{array}{l}\text { E. gracilis . . } \\
\text { H. knickerbockeri } \\
\text { G. fasciatus... } \\
\text { G. limnaeus . . }\end{array}$ & $\begin{array}{l}\text { Nov. 3, A. M. } \\
\text { July } 15, \text { A. M. } \\
\text { July } 18, \text { A. M. } \\
\text { Aug. } 2, \text { P. M. } \\
\text { Feb. } 16, \text { A. M. } \\
\text { Feb. } 3 \text {, A. M. }\end{array}$ & $\begin{array}{l}\text { Nov. } 11, \text { A. M. } \\
\text { July } 23, \text { P. M. } \\
\text { July 26, A. M. } \\
\text { Aug. 10, P. M. } \\
\text { MIch. 6, A. M. } \\
\text { Feb. 24, A. M. }\end{array}$ & $\begin{array}{r}8 \\
8,5 \\
8 \\
8 \\
18 \\
21\end{array}$ & $\begin{array}{l}184^{\circ} \mathrm{C} \\
200^{\circ} \mathrm{C} \\
192^{\circ} \mathrm{C} \\
184^{\circ} \mathrm{C} \\
303,48^{\circ} \mathrm{C} \\
380,8^{\circ} \mathrm{C}\end{array}$ & $\begin{array}{l}23^{\circ} \mathrm{C} \\
23,6^{\circ} \mathrm{C} \\
24^{\circ} \mathrm{C} \\
23^{\circ} \mathrm{C} \\
16,9^{\circ} \mathrm{C} \\
14,8^{\circ} \mathrm{C}\end{array}$ \\
\hline
\end{tabular}

\section{The Young: Activities and Relation to Parent.}

The newly hatched young vary in size as indicated in table XI, p. 23. There is a noticable difference in the degree of activity between those of G. limnaeus und E. gracilis. Immediately after hatching the former are capable swimmers. Generally those under observation ${ }^{1}$ ) swam about the watch glass until they collided with some aquatic plant and if the plant happened to be a specimen of Elodea, Myriophyllum or Utricularia, the young would begin to climb up the stem into the axils of the leaves or into the infolding leaf bud. Here they would rest or begin to feed. Many arose to the surface only to climb among the rhizoids of a floating liverwort (Ricciocarpus). These rhizoids not only constituted a safe retreat for the young but also furnished in themselves tender plant food for which the former exhibited a strong desire. Other young crawled underneath bits of dead leaves and bottom rubbish. In other aquaria the young, even when nearly mature, burrowed out of sight in the bottom sediment consisting

1) These young amphipods were hatched from eggs which had previously been taken from females and isolated in watch glasses. 
largely of finely divided plant remains. They would always resort to this method of concealment when disturbed.

They were often greatly excited when bits of freshly killed Asellus or Planorbis were thrown into the water and in a few minutes nearly all would collect about the food. - At such a time they showed a pugnacity equal to that of their parents and very similar to that observed by Andrews (1907) in the case of the young of Astacus leniusculus in the third larval stage. Often several young would seize the same piece with their mandibles and this would be followed by a vigorous use of all of the thoracic appendages, and a violent "kicking" of abdomens which usually tore the food particle into as many shreads as there were amphipods. Each one carrying a choice morsel would subsequently swim away to a dark corner.

The young amphipods at first found the food thus administred quite by accident. The final reactions, however, were undoubtly influenced by the sense of smell or taste, or perhaps both. Fluids given off from the food gradually diffused through the water to a short distance in all directions. Any amphipod coming into this region instantly changed its behavior. Ordinarily a young amphipod swims in a straight or a somewhat curved path using its pleopods only. However, when one enters the region polluted with fluids from the food, it quickly, becomes very erratic both in its course and in its movements. It now jumps first in one direction and then in another by flexing and reflexing its abdomen, and at the same time moving the antennae in wide sweeps. Whenever it touches unpolluted water it immediately turns back. This may continue for a number of seconds or perhaps a minute but the general movement of the animal is gradually towards the food which it eventually touches. One jump and the particle is grasped by the gnathopods and appendages of the mouth while the peraepods and abdomen continue to move vigorously. If the piece of food be not large the young amphipods will likely carry it away bodily.

The young of E. gracilis are smaller than those of the preceding species and unlike them are incapable of swimming more than a few millimeters without becoming exhausted. During the first day they exhibit no inclination to feed or to climb and but a slight desire to conceal themselves under bottom debris. In the course of a few days however, they have gradually acquired all the activities of the young of G. limnaeus although these activities are never so marked as they are in the latter species. 
Miss Smallwood indicates (1905) that the young of Orchestia palustris voluntarily leave the brood sac from three to four days after hatching. Some individuals which were forcibly taken from the brood sac gradually reentered it.

On May 24, 1909, a pair of E. gracilis were isolated in a dish of water containing aquatic plants. The female contained eggs which hatched two days later. On the twenty eighth, one young had left the pouch and was found swimming about. On May 20, six young were found either swimming about or feeding among the plants. Two hours later these six could not be found. Upon gently tapping the mother, four young left the pouch and swam about until one by one they collided with their parent, clung to the hair-like processes from the lamellae forming the brood pouch and finally wedged themselves into the pouch. On June first one young voluntarily issued from the brood pouch, swam to a piece of Spahagnum, secured a good meal from the same and then began to swim aimlessly about the dish. In time it came in contact with its parent and immediately reentered her pouch.

A like behavior of other individuals of the same brood was noted on each succeeding day until June 5 th., when all young had left the pouch and none were observed to reenter. The observations point to an instinct analogous to that which Andrews has shown (1907) to be highly developed in the young of the second and third larval stages of Astacus leniusculus and Cambarus affinis respectively. None of the young of Hyalella or G. fasciatus was observed to re-enter the brood pouch after once having left it. The activities of the young of these species, however, were not followed closely and this particular habit may have escaped observation.

In the following table VI is given a summary of the data indieating the length of time the young of each of the four species remain in the brood pouch.

It was observed in the case of Hyalella, G. limnaeus and G. fasciatus that the exit ef the young might be hastened in two ways. 1. The females usually mate a second time before the young of the first broods have left the pouches. The struggle of the males in such cases usually forces the exit of the young. 2. The females occasionally moult prematurely, when the young are gotten rid of with the cast skins. In such cases the young were never observed to re-enter the pouches of the living females but were often found in the cast skins. 
Table VI.

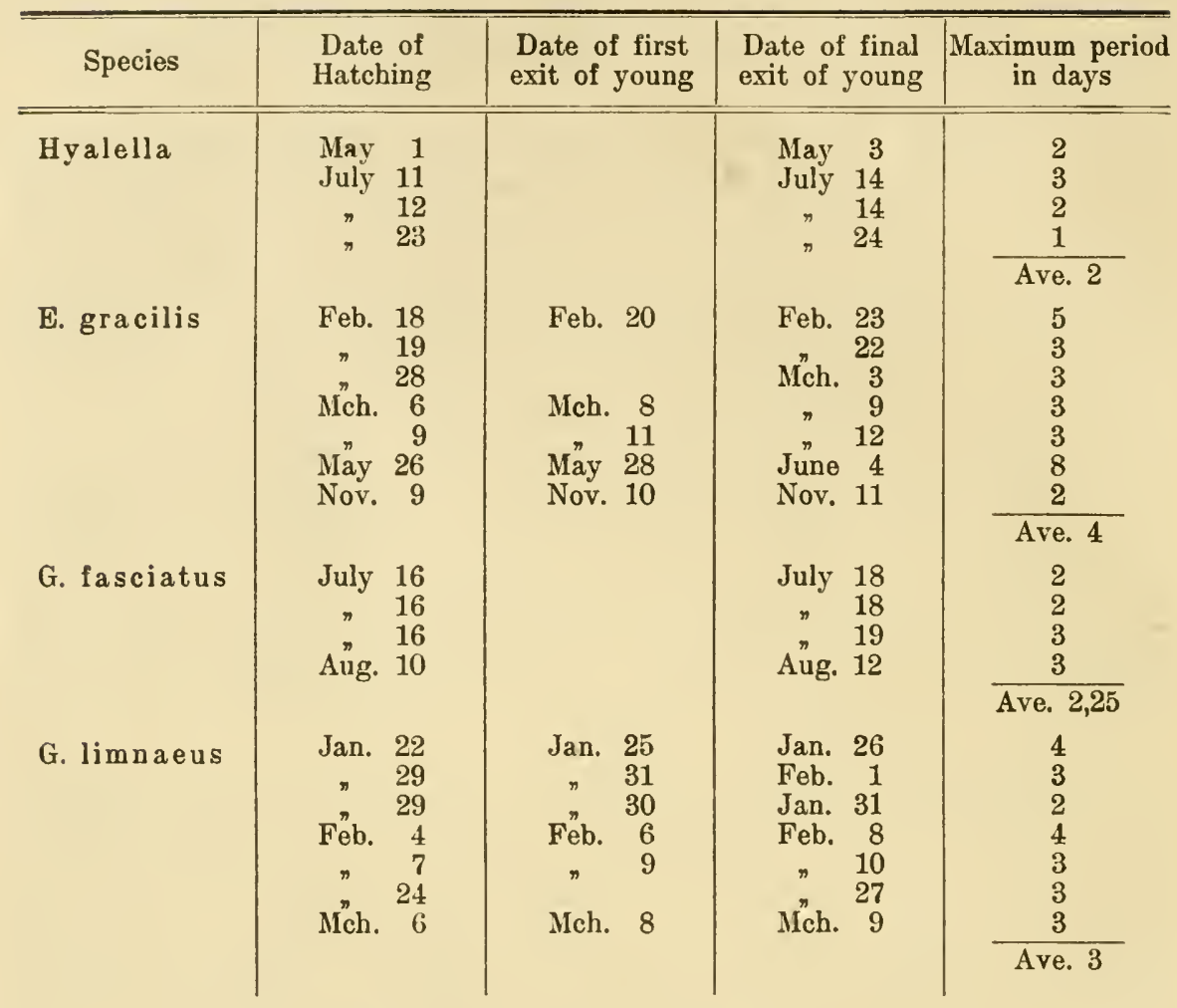

7. Recurrence of the Reproductive Activities.

A. Della Valle has shown (1889), and the writer has ample data to verify the assertion, that it is only possible for oviposition to take place immediately or very soon after the moulting of the female. The question arises, does it take place after every moult during the reproductive period? It is evident that this would depend upon the periodic maturation of the sexual elements of both male and female and also upon the chance meeting of the two animals at the proper time.

It has been indicated in the preceeding page that males of at least two species may mate during a number of days between two moults and that the sexual impulse may likewise appear during a like period between the two subsequent moults. It is believed by the writer that males of G. fasciatus and E. gracilis are not unlike those of the other two species in this respect. The great frequency in collections made throughout the yearly reproductive period, of males mated with 
females already carrying eggs or young, leads one to believe that males in the proper physiological condition for mating are at all times abundant enough to supply each female with a consort at a time when the latter is capable of oviposition. Thus we have only to consider the rate of periodic maturation of ova in order to understand the rate of recurrence of the reproductive activities.

It can be easily observed that at a time just prior to moulting the ovaries become enlarged and very dark in color. This has been observed to occur periodically throughout the yearly reproductive period in aquarium specimens and would thus favor the view that oviposition may take place after every moult, of the female.

The attempt was made to verify it experimentally but only partial success was attained. In experiments performed with pairs of the two species, G. fasciatus and Hyalella, three successive sets of eggs were secured from a single female in each case, after the same number of moults. In the case of G. limnaeus only two sets were obtained in as many moults. No success resulted from a like treatment of pairs of E. gracilis.

The method of procedure was usually as follows; - several mated pairs of each species were at first placed in as many small glass dishes containing aquatic plants and pond water. These were kept covered with glass except when the daily observations were to be made. Every other day the amphipods were fed pieces of freshly killed Asellus. After the first moult and subsequent deposition of eggs, in every case the male was removed to a separate dish. All dishes were numbered and proper data kept on separate numbered sheets. A moderate sized aquarium was stocked plentifully with extra males in order that a supply of breeding males might be available at all times.

Whenever the eggs of one female hatched her former mate was again placed with her. If mating did not take placed within a few minutes another male was substituted. This treatment was continued until the female was usually mated a second and sometimes a third time. In the case of one female Hyalella, the right male was not found until the second day after the female had moulted. The two mated and on the morning of the third day another set of eggs was present which eventually hatched quite normally.

The following tabulated data are representative of those secured in the above described manner.

From this table one can see that in the case of two forms at least, three sucessive sets of eggs may be extruded immediately follow-

Embody, Amphipods, Biol. Suppl., III. Serie, 1911. 
Table VII.

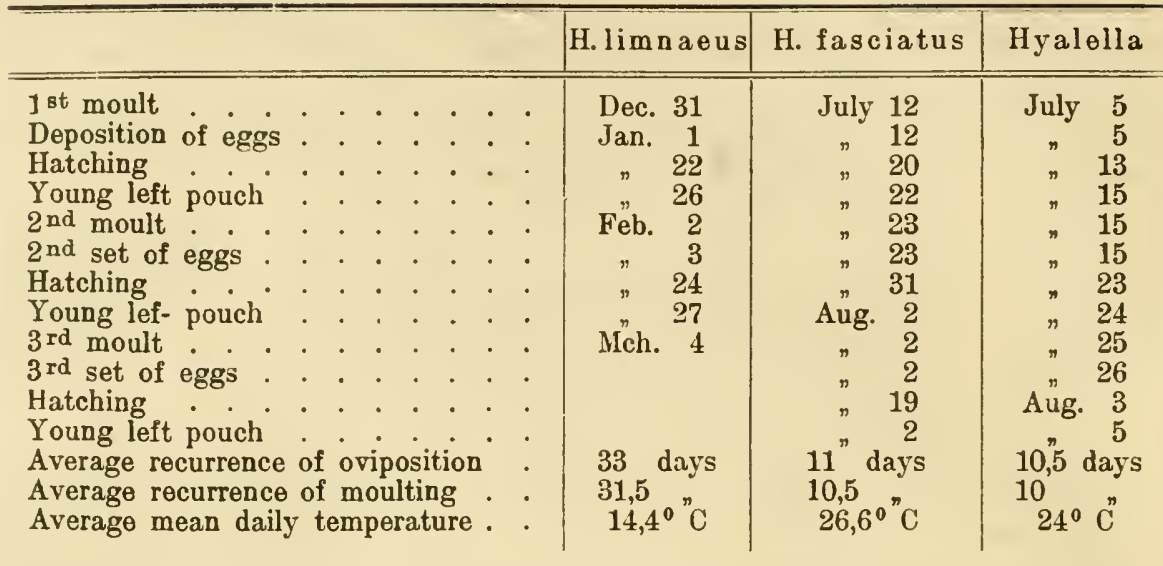

ing the same number of moults. It is also indicated that the average period of recurrence of ecdysis is very nearly equal to that of oviposition, a fact which will be of assistance in determining the possible number of sets produced by a single female during the total reproductive period.

3. Moulting of Adults.

During the fall of 1909 and winter of 1910 a female each of Hyalella and G. fasciatus were isolated in dishes as has been previously described and the rate of moulting observed.

The two moulted as follows:

Hyalella.

$1^{\text {st }}$ moult.

$3^{d}$

$4^{\text {th }}$

$5^{\text {th }}$

$6^{\text {th }}$

Nov. 24, Dec. 10

Period $=16$ dys., 14

18

Jan. 26 , Feb. 9.

G. fasciatus.

1 st $2 \mathrm{~d}$ $3^{\alpha}$ $4^{\text {th }}$ $5^{\text {th }}$ $6^{\text {th }}$ $7^{\text {th }}$

Nov. 1, Nov. 16, Nov. 24, Dec. 8, Dec. 23, Jan. 6, Jan. 20, Feb. 8, Feb. 27 $\begin{array}{lllllll}\text { Period }=15 \text { dys., } & 8 & 14 & 15 & 14 & 14 & 19\end{array}$

Comparing the data thus secured, it was thought that by keeping a record of the daily mean temperatures of the air in the immediate vicinity of the aquaria, a partial correlation of temperature with the rate of moulting might be disclosed. A number of females of each of the four species were therefore placed in as many dishes and their rates of moulting, together with the mean daily temperature of the room were recorded. 
The data secured in this manner are condensed in the following table. They are more or less fragmentary but in a general way will serve our purpose.

Table VIII.

\begin{tabular}{|c|c|c|c|c|c|c|c|}
\hline \multicolumn{2}{|c|}{ G. limnaeus $q$} & \multicolumn{2}{|c|}{ G. fasciatus $q$} & \multicolumn{2}{|c|}{ E. gracilis 우 } & \multicolumn{2}{|c|}{ Hyalella $q$} \\
\hline $\begin{array}{l}\text { Pd. bet- } \\
\text { ween } \\
\text { moults } \\
\text { in days }\end{array}$ & $\begin{array}{c}\text { Ave. mean } \\
\text { daily } \\
\text { temperatures }\end{array}$ & $\begin{array}{l}\mathrm{Pd} \text {. in } \\
\text { days }\end{array}$ & $\begin{array}{c}\text { Ave. mean } \\
\text { daily } \\
\text { temperatures }\end{array}$ & $\begin{array}{c}\mathrm{Pd} \text {.in } \\
\text { days }\end{array}$ & $\begin{array}{c}\text { Ave. mean } \\
\text { daily } \\
\text { temperatures }\end{array}$ & $\begin{array}{l}\mathrm{Pd} \text {. in } \\
\text { days }\end{array}$ & $\begin{array}{l}\text { Ave. mean } \\
\text { daily } \\
\text { temperatures }\end{array}$ \\
\hline $\begin{array}{l}38 \\
34 \\
32 \\
30 \\
30 \\
26\end{array}$ & $\begin{array}{l}9^{\circ} \mathrm{C} \\
12,5^{\circ} \mathrm{C} \\
14^{\circ} \mathrm{C} \\
15,5^{\circ} \mathrm{C} \\
15,7^{\circ} \mathrm{C} \\
17^{\circ} \mathrm{C}\end{array}$ & $\begin{array}{l}19 \\
15 \\
13 \\
13\end{array}$ & $\begin{array}{l}16^{\circ} \mathrm{C} \\
16,4^{\circ} \mathrm{C} \\
17,3^{\circ} \mathrm{C} \\
17,4^{\circ} \mathrm{C}\end{array}$ & $\begin{array}{l}19 \\
15 \\
11 \\
10 \\
10 \\
10\end{array}$ & $\begin{array}{ll}15,2^{0} & \mathrm{C} \\
17,2^{0} & \mathrm{C} \\
23,2^{\circ} & \mathrm{C} \\
21,3^{0} & \mathrm{C} \\
24,1^{2} & \mathrm{C} \\
24,3^{\circ} & \mathrm{C}\end{array}$ & $\begin{array}{l}19 \\
13 \\
11 \\
11 \\
10 \\
10 \\
10\end{array}$ & $\begin{array}{l}16,7^{\circ} \mathrm{C} \\
16,5^{\circ} \mathrm{C} \\
18,1^{\circ} \mathrm{C} \\
18.5^{\circ} \mathrm{C} \\
19^{\circ} \mathrm{C} \\
20,7^{\circ} \mathrm{C} \\
24^{\circ} \mathrm{C}\end{array}$ \\
\hline
\end{tabular}

It can be seen that in general the period between moults increases as the average mean daily temperature decreases. However the individual variation is so great and the data so fow that no definite relation between the two can be established. Miss Mary T. Harmon gives (1907 pp. 70-75) some observations upon the rate of moulting of several individuals of Gammarus (sp?) kept in glass jars between July 8 and August 10, which had been variously operated upon. In some cases the right hind leg had been removed in others, both hind legs. According to her statements, when one hind leg had been severed, the average rate of moulting was fifteen days with extremes of twelve and twenty-three days; when both hind legs had been so treated, the average was sixteen and two-sevenths days with extremes of twenty and thirteen. We are not informed however, as to the temperature conditions nor is any statement made concerning the rate of the moulting of unmutilated specimens.

\section{Moulting of Young.}

Eggs of three species, G. limnaeus, E. gracilis and Hyalella were placed in different watch glasses just prior to hatching. The resulting young were separated in other watch glasses, each one of the latter having a serial number. The time between hatching and the first moult together with the mean daily temperatures were recorded. The results are presented in the table which follows. 
Table IX.

\begin{tabular}{|c|c|c|c|c|c|c|c|c|c|c|c|c|}
\hline \multicolumn{5}{|c|}{ G. limnaeus } & \multicolumn{4}{|c|}{ E. gracilis } & \multicolumn{4}{|c|}{ Hyalella } \\
\hline & $\begin{array}{c}\text { Date of } \\
\begin{array}{c}\text { Hateh- } \\
\text { ing }\end{array}\end{array}$ & $\begin{array}{c}\text { First } \\
\text { moult }\end{array}$ & न1 & $\mid \begin{array}{c}\text { Ave. } \\
\text { mean } \\
\text { temp. C }\end{array}$ & $\begin{array}{c}\text { Date of } \\
\text { Hatch- } \\
\text { ing }\end{array}$ & $\begin{array}{l}\text { First } \\
\text { moult }\end{array}$ & 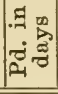 & $\mid \begin{array}{c}\text { Ave. } \\
\text { mean } \\
\text { temp. C }\end{array}$ & $\begin{array}{c}\text { Date of } \\
\text { Hatch- } \\
\text { ing }\end{array}$ & $\begin{array}{c}\text { First } \\
\text { moult }\end{array}$ & 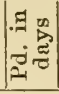 & $\begin{array}{c}\text { Ave. } \\
\text { mean } \\
\text { temp. C }\end{array}$ \\
\hline $\begin{array}{r}1 \\
2 \\
3 \\
4 \\
5 \\
6 \\
7 \\
8 \\
9 \\
10 \\
11\end{array}$ & $\begin{array}{cr}\text { Jan. } & 22 \\
n & 22 \\
n & 29 \\
n & 29 \\
\text { Féb. } & 29 \\
\text { Feb. } & 4 \\
" & 7 \\
n & 7 \\
\text { M"ch. } & 24 \\
\text { M. }\end{array}$ & 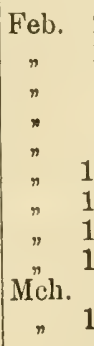 & \begin{tabular}{r|r}
2 & 11 \\
2 & 11 \\
6 & 8 \\
6 & 8 \\
7 & 5 \\
1 & 5 \\
3 & 5 \\
4 & 7 \\
4 & 7 \\
4 & 8 \\
3 &
\end{tabular} & \begin{tabular}{c|}
$14,7^{\circ}$ \\
$14,4^{\circ} 4^{\circ}$ \\
$14,5^{\circ}$ \\
$18,3^{\circ}$ \\
$14,3^{\circ}$ \\
$n$ \\
$17^{n}, 7^{\circ}$ \\
$18,13^{\circ}$
\end{tabular} & $\mid \begin{array}{cc}\text { Feb. } & 28 \\
\text { Maỹ } & 26\end{array}$ & $\begin{array}{l}\text { Mch. } 8 \\
\text { Mch. 9 } \\
\text { June 4 }\end{array}$ & $\begin{array}{l}8 \\
9 \\
9\end{array}$ & $\begin{array}{l}19,2^{\circ} \\
19^{0} \\
17,6^{\circ}\end{array}$ & $\begin{array}{ll}\text { Nay } 25 \\
\text { July } 23\end{array}$ & $\mid \begin{array}{lr}\text { June } & 3 \\
\text { July } & 28\end{array}$ & $\begin{array}{l}9 \\
5\end{array}$ & $\begin{array}{l}17,3^{0} \\
25,3^{\circ}\end{array}$ \\
\hline
\end{tabular}

In the case of G. limnaeus, it will be noticed that the shortest period (7 days) between the date of hatching and that of the first moult occurred in water having the lowest as well as in that having next to the highest mean temperature recorded. Again, the longest period (11 days) occurred at a temperature even .4 of a degree higher than that for two of the three cases of the shortest period. This in dicates clearly that a factor other than temperature exerts a strong influence over the first moult.

Three individuals of the same brood of G. limnaeus and one each of E. gracilis and Hyalella were carried through three or more consecutive moults from the date of hatching. The data concerning these is shown in the following table.

Table X.

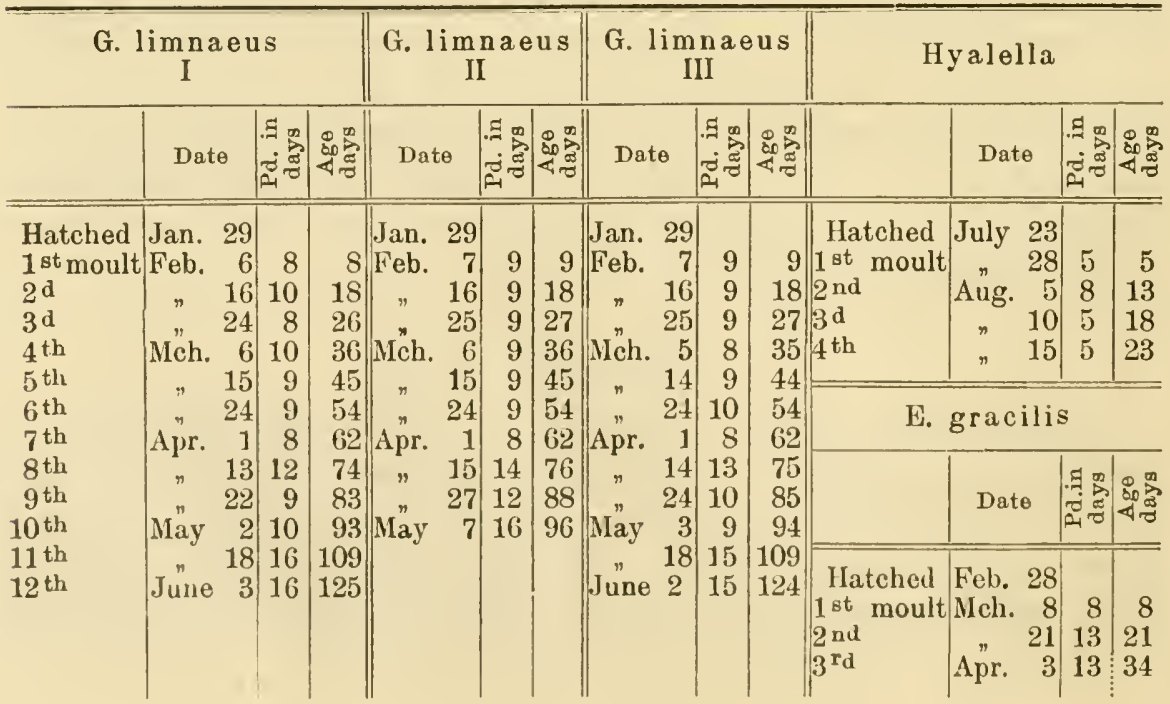




\section{Method of Moulting.}

A number of individuals, both adults and young, of all four species were observed in the act of moulting. So far as could be determined there was no difference in the process between adults and young nor between the individuals of any two species.

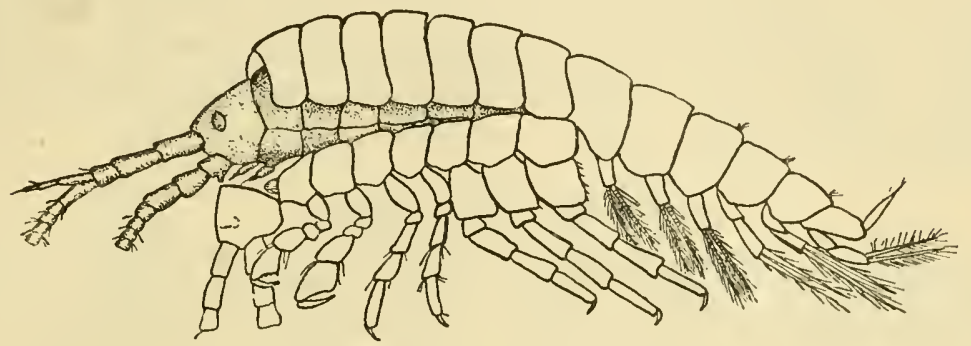

Fig. 4. Gammarus, moulting.

Briefly stated the process took place as follows; - That part of the exoskeleton covering the anterior part of the head, the antennae and other cephalic appendages was the first to become loosened. A fissure appeared between this portion and the first dorsal plate (fig. 4) which gradually widened. The gnathopods were now used in such a manner as to assist in pulling the skin over the head and away from the appendages of the latter. However this skin remained permanently attached by its mid postero-ventral marign to the remaining portion of exoskeleton. Steady and deliberate wave like movements of the body took place at intervals of about 8 or 10 seconds. The effect of these was to cause a split on either side between the dorsal and coxal plates which eventually extended from one half to two thirds of the distance to the telson. As the movements continued, the first and second gnathopods in turn were withdrawn followed by the first and sometimes the second peraeopods. A final and noticeably stronger wave like movement resulted in the loosening of the posterior portion of the old skin from which the amphipod now deliberately crawled. The whole process took place normaly in from 7 to 10 minutes of which the greater amount of time was required in the removal of the head piece and that covering each gnathopod.

One female Hyalella began to moult at 9,30 A. M. The skin split normally, followed by the sliding off of the head piece and the withdrawal of the gnathopods. The animal attempted to extricate the peraepods but without success, for at 11,30 A.M., it was still struggling. 
The movements continued with diminishing intensity and at $12 \mathrm{M}$, the amphipod was dead without having crawled from the old skin.

Four other similar cases came under observation. A fifth specimen (G. limnaeus), moulted in two hours completely shedding the old skin but was found dead ten minutes later.

It was very evident that the moulting of the female at least, if for any reason prolonged might bring about such a weakened condition as would result in death. Such a weakened female even if possessed of sufficient vitality to live through the process, might fall an easy victim to a vicious and hungry male.

\section{Growth of young.}

Broods of young representing the four speciers here treated and whose hatching dates were known, were isolated in different aquaria each of about a gallon capacity. Bottom sediment including a fow dead leaves was supplied to each aquarium together with living plants of Elodea, Chara and Ricciocarpus. It was customary to take three individuals of each species at different ages and kill them in 95 percent alcohol containing 7 percent formaldehyde. ${ }^{1}$ ) They were then carefully straightened out and with a short steel measure graduated in hundreds of an inch, the length of each individual exclusive of the antennae was taken by the aid of a disecting microscope. The results, while not complete, cover a long enough period to show considerable diversity in the rate of growth of certain species and to throw some light upon the question concerning the age at which each form reaches sexual maturity.

All recorded measurements reduced to millimeters together with the ages in days are tabulated as follows on p. 23.

'The four curves on page 24 have been plotted by using the data (lengths and ages) in table XI as coördinates.

Of the four species it can be seen that G. limnaeus and G. fasciatus, grow most rapidly, Hyalella ranking third and E. gracilis last.

The young amphipods which furnished the data in Table XI were watched closely with the hope that some might exhibit signs of sexual activity. - The Hyalellas alone rewarded the effort. At the age of forty-three days two pairs of young were mated and on the forty-fifth

1) With theso proportions it was found that the fixed amphipods retained the size and form of the living ones. 
Distribution, Food and reproductive Capacity of some fresh-water Amphipods. 23

Table XI.

\begin{tabular}{|c|c|c|c|c|c|c|c|}
\hline \multicolumn{2}{|c|}{ G. limnaeus } & \multicolumn{2}{|c|}{ G. fasciatus } & \multicolumn{2}{|c|}{ E. gracilis } & \multicolumn{2}{|c|}{ Hyalella } \\
\hline Age & Length & Age & Length & Age & Length & Age & Length \\
\hline $\begin{array}{l}0 \\
5\end{array}$ & $\begin{array}{l}2,16 \\
2,3\end{array}$ & 0 & 1,53 & 0 & 1,27 & 0 & 1,27 \\
\hline 10 & 2,5 & 10 & 2,4 & 10 & 1,43 & 10 & 1,63 \\
\hline 20 & 3,06 & 20 & 3,32 & 20 & 1,76 & 20 & 2,04 \\
\hline 25 & 4,3 & & & & & 25 & 2,45 \\
\hline 30 & 5,26 & 30 & 4,6 & 30 & 2,29 & 30 & 2,9 \\
\hline 40 & 7,5 & 40 & 5,86 & & & 40 & 3,2 \\
\hline 50 & 1 & & & & & 50 & 3,5 \\
\hline 80 & 8,16 & & & 80 & 2,75 & & \\
\hline $\begin{array}{l}100 \\
140\end{array}$ & $\begin{array}{r}9,43 \\
10,71\end{array}$ & & & 140 & 3,32 & & \\
\hline 180 & 11,73 & 180 & 9,32 & 180 & 3,57 & 180 & 6,4 \\
\hline
\end{tabular}

day six eggs were laid by each female. A third young female which possesed enlarged dark colored ovaries was placed with a large male which had just been separated from its mate. Mating was immediately accomplished and on the forty-fifth day, six eggs had been deposited. Two other pairs mated and laid eggs at the age of fifty-one days and still another female deposited eggs at the age of sixty days. So far as could be determined the eggs of all young females developed normally and hatched in due time.

As a check upon these results, large collections of Hyalella with eggs in their brood pouches were made. Only the smallest females were kept and their lengths taken. In this manner the smaller breeding female was found to be $3,06 \mathrm{~mm}$ long and to possess six eggs. If we examine the data for Hyalella in table XI and also the curve of growth it is seen that the $3,06 \mathrm{~mm}$ female must have been approximately thirty-five days old.

Collections of breeding females of the other three species were made and the smallest ones measured, this furnishing the only available means of determining approximately the ages of the youngest sexually mature females. If these data are likewise compared with those in table XI and with the respective curves of growth, the approximate ages at which individuals of each species reach sexual maturity may be obtained.

The results of the foregoing procedure may be conveniently tabulated as follows in table XII. 
G. C. Embody.

If the data contained in the above table represent approximately the true conditions in the vicinity of Ithaca, it is evident that aside

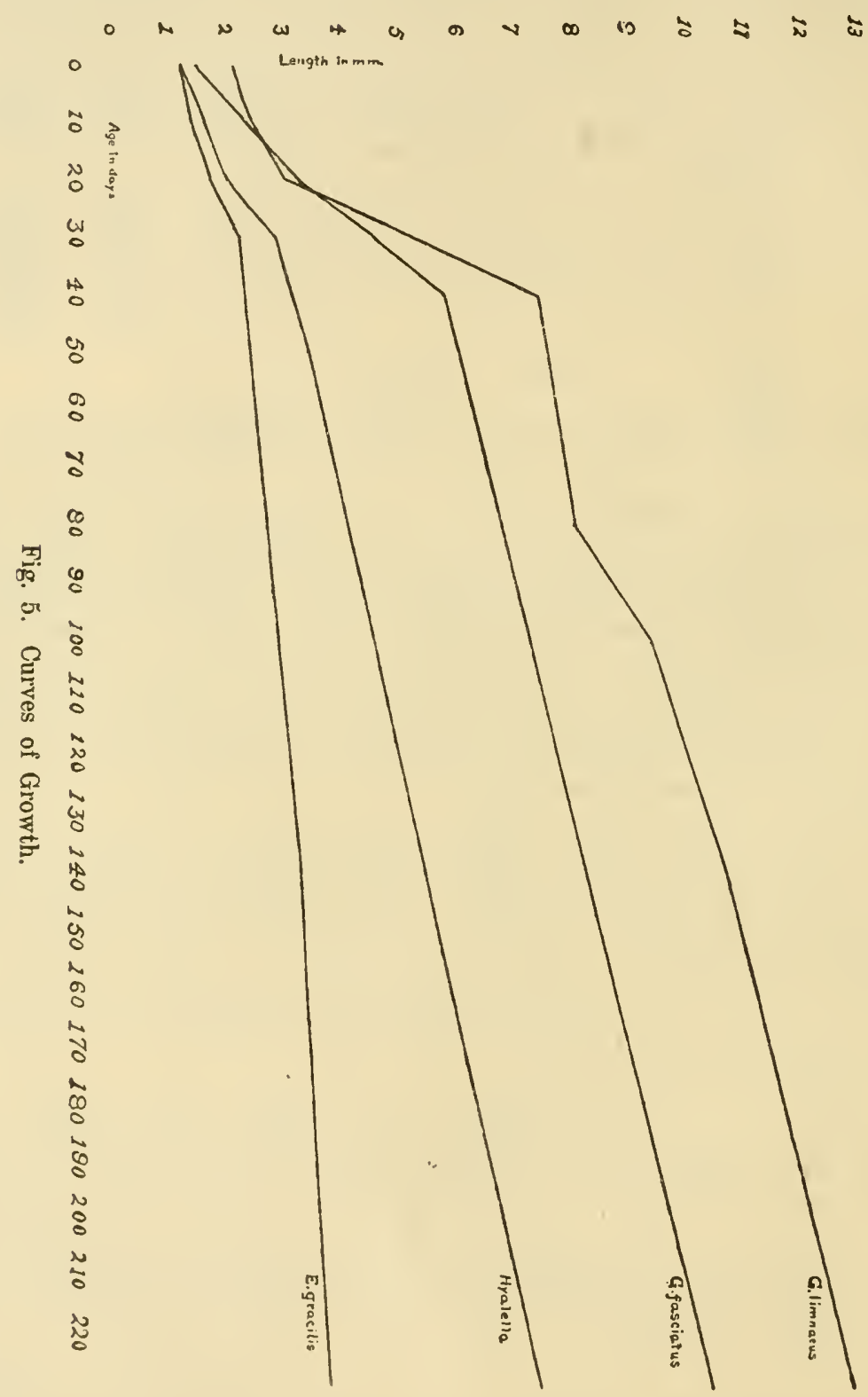

from the production of several successive broods by a single pair, it is possible for the reproductive capacity of every species, excepting, 
Distribution, Food and reproductive Capacity of some fresh-water Amphipods.

Table XII. Youngest Breeding females.

\begin{tabular}{|c|c|c|c|}
\hline Species & $\begin{array}{c}\text { Age of smallest } \\
\text { females }\end{array}$ & $\begin{array}{l}\text { Length of smallest } \\
\text { female in } \mathrm{mm}\end{array}$ & No of eggs \\
\hline $\begin{array}{l}\text { G. limnaeus } \ldots \ldots \ldots \\
\text { G. fasciatus . . . . . } \\
\text { E. gracilis . . . } \\
\text { Hyalella . . . }\end{array}$ & $\begin{array}{l}93 \text { dys. } \\
39 \text { dys. } \\
\left.497 \text { dys. }{ }^{1}\right) \\
35 \text { dys. }\end{array}$ & $\begin{array}{l}9 \\
5,8 \\
5,6^{21} \\
3,06\end{array}$ & $\begin{array}{r}8 \\
6 \\
25 \\
6\end{array}$ \\
\hline
\end{tabular}

E. gracilis, to be further increased by the appearance of a second, a third, or even later generations during the yearly reproductive period.

\section{The Possible Progeny from a Single Pair in one Year.}

With the data now at hand it is possible to calculate approximately the total number of young resulting directly or indirectly during the period of one year from a pair of each species. In order to facilitate these calculations and to make them more easily comprehended, the essential data have been condensed in the following table.

Table XIII.

\begin{tabular}{|c|c|c|c|c|}
\hline & G. limnaeus & G. fasciatus & E. gracilis & Hyalella \\
\hline 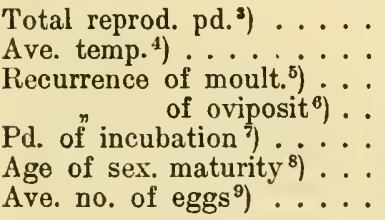 & $\begin{array}{l}266 \\
9^{0} \mathrm{C} \\
38 \mathrm{dys} \\
38 \quad " \\
35 \quad 7 \\
93 \quad " \\
25\end{array}$ & $\begin{array}{l}199 \\
17,9^{\circ} \mathrm{C} \\
12-13 \\
12,5 \\
11 \\
39 \\
22\end{array}$ & $\begin{array}{l}299 \text { dys. } \\
17,16^{\circ} \mathrm{C} \\
15-16 \\
15,5 \\
12 \\
497 \\
45\end{array}$ & $\begin{array}{l}152 \\
20,14^{0} \mathrm{C} \\
10 \\
10 \\
8 \\
35 \\
18\end{array}$ \\
\hline
\end{tabular}

By the use of these data together with thpse in Table IV, p. 12, and by reference to the four curves of growth (p. 24), the following

1) This value was obtained by continuing the curve for E. gracilis until it reached a point indicated by the length 5,6. The corresponding abscissa was 497 . This assumes that the rate of the increase in length remains constant as the young reaches maturity. This rate probably decreases which would make the age of the smallest sexually mature female greater than 497 days.

2) Although some fifty small females were measured and this one was the smallest by only a small margin, younger ones may yct be found breeding in other localities.

3) Table II, p. 6.

4) Table III, p. 7.

5) Table VIII, p, 19.

6) Equal to periods between moults.

7) Equal to periods between moults less brooding period (Table VI, p. 16).

8) Table XII, p. 25.

9) Table IV, p. 12. 
schedules of generations, number of broods in each, and the number of eggs produced by each brood, have been made.

E. gracilis.

In the case of this species, a computation of the yearly productiveness is a simple matter for the reason that the young grow so slowly a second generation is not produced until the second year.

If a single pair breed every 15,5 days during a total period of 299 days, they will breed approximately 19 times. The average number of eggs produced at any one time is 45 (table IV). Hence the total number produced during the period of 299 days is 855 .

Schedule I. G. limnaeus.

One pair produces an average of 25 eggs, 7 times in 266 days

Total 175 Generation I.

Brood 1. 12 prs. $^{1}$ ) ave., 16 eggs $^{2}$ ) each on $128^{\text {th }}{ }^{3}$ ) dy. and 3 times thereafter 768 Generation II.

Brood 1. 8 prs. ave., $8^{4}$ ) eggs on $255^{\text {th }}$ dy. and 0 times thereafter 64 Brood 2. $\left.{ }^{5}\right) 12, \quad 9$ " 12 " $166^{\text {th }}$ " 2 " 24 Brood 3. 12 " 12 " 8 " $204^{\text {th }} ", 192$

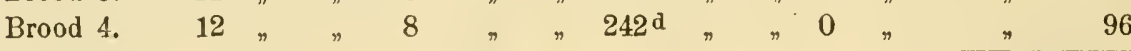

Grand total 1619

1) The weak point in these calculations lies in the assumption that on an average the number of males in any brood is equal to the number of females. There were no characters upon which the writer could rely for separating young males from females. Hence no accurate knowledge is at hand for determining the numerical ratio of their occurrence. The assumption is based solely upon observations of a single brood of eleven Hyalellas of which five young subsequently proved their sex by mating and laying eggs.

1) This average is secured in the following manner: - The individuals of brood 1 will become sexually mature at the age of 93 days, approximately $9 \mathrm{~mm}$, long (see curves p. 24) and the females will lay 8 eggs (table IV). They will breed 4 times during the period of 266 days. At the fourth breeding date they will be 107 days old ( $3 \times 38+93), 7,5 \mathrm{~mm}$, long (p. 24) and will lay about $24 \mathrm{eggs}$ (table IV). The mean between 8 and 24 is 16 and may be taken as the average number of eggs produced at any one breeding.

3) The eggs producing these young required 35 days for development and the young matured 93 days later; hence 128 represents the day of the first and only oviposition.

4) These pairs will breed only once, at age of 93 days and will therefore produce but 8 eggs, (table IV).

i) The young resulting from broods 2,3 and 4 will not mature within the linit of 266 days. 
Schedule II. G. fasciatus.

One pair produces an average of 22 eggs, 15 times in 199 days

Generation I.

Brood 1. 11 prs. ave. 16 eggs each on the $50^{\text {th }}$, day and 11 times thereafter 2112 Generation II.

Brood 1. 8 pairs average, 15 eggs on $100^{\text {th }}$ day and 7 times thereafter 960 Generation III.

Brood 1. 7 pairs average, 10 eggs on $150^{\text {th }}$ day and 3 times thereafter 280

Brood 2. 7 " $\quad 9$ " $162,2^{\text {th }}$ " 2 " 2 n 189

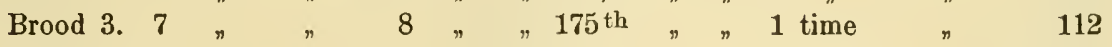

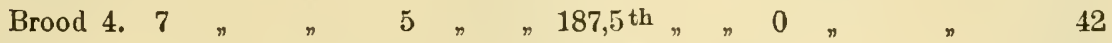

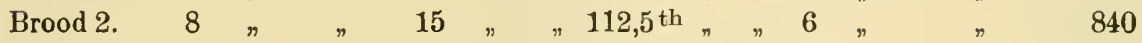

Brood 1. 7 " 9 " $162,5^{\text {th }}$ " 2 ", 189

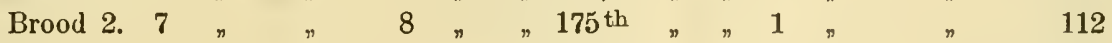

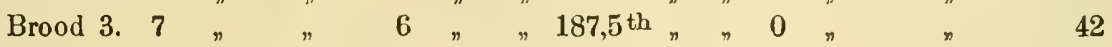

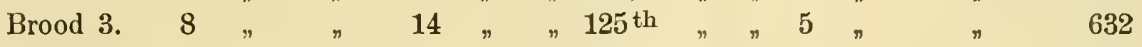

Brood 1. $7 " \quad$ " 8 " $175^{\text {th }} " n 1 " 1012$

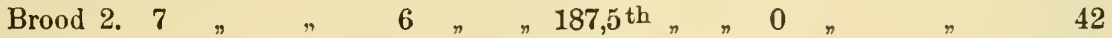

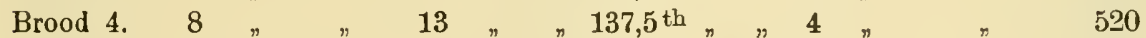

Brood 1. 6 " $" 6$ " $" 187,5^{\text {th }}$ " $" 0$ n 0 "

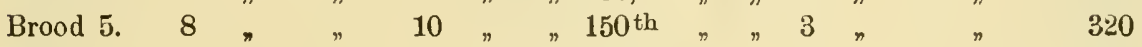

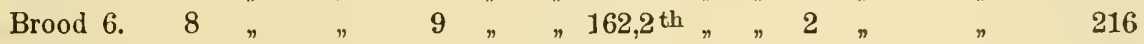

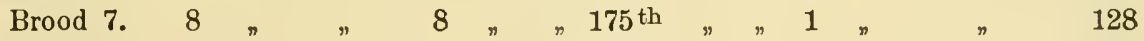

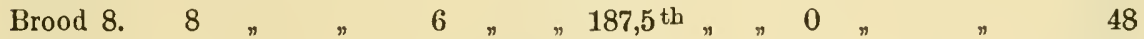

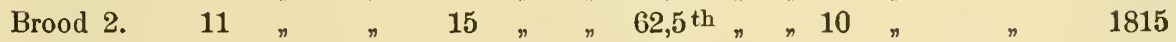

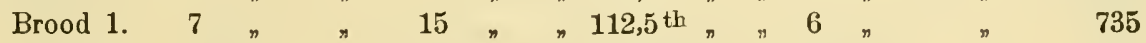

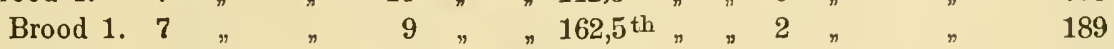

Brood 2. 7 " 8 " $8175^{\text {th }} "$ " 1 " 112

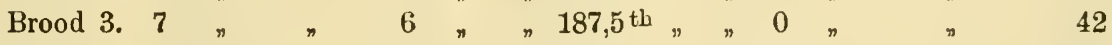

Brood 2. 7 n 714 n $7125^{\text {th }}$ n $n 5$, 588

Brood 1. 7 " 8 " $175^{\text {th }}$ " 11 " 112

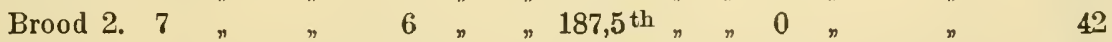

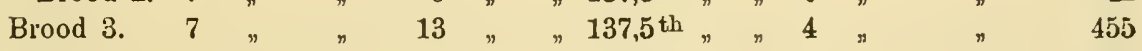

Brood 1. 6 n $\quad 6$ " $, 187,5^{\text {th }} "$ " 0 " $\quad$ n 36

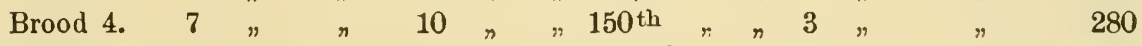

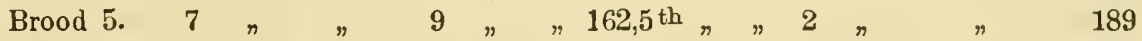

Brood 6. 7 n $" 8$ " $8175^{\text {th }} n$ n 1 n $n$

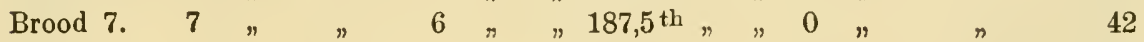

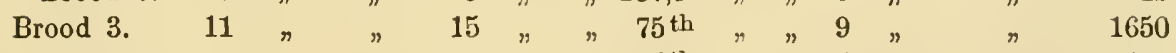

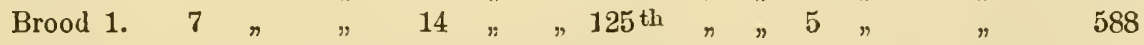

Brood 1. 7 " 8 " $175^{\text {th }}$ " 11 n 12

Brood 2. 7 n 6 n $, 187,5^{\text {th }}$ n 0 n 0 n 42

Brood 2. 7 " 713 n $, 137,5^{\text {th }}$ n, 4 , 4 n 455

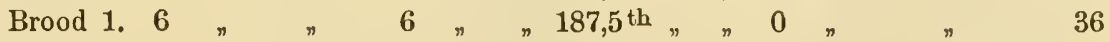

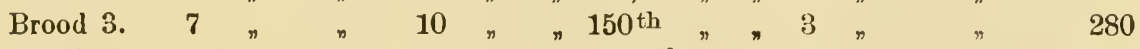

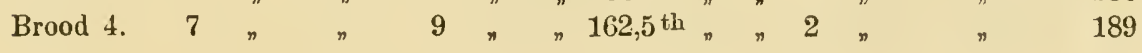


G. C. Embody.

Brood 5. 7 prs. ave. 8 eggs on $175^{\text {th }}$ day and 1 times thereafter 112

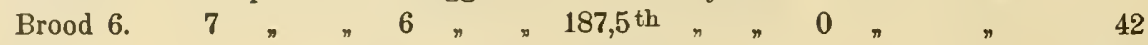

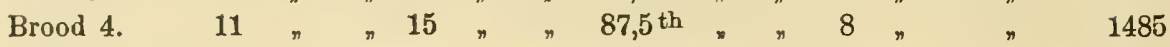

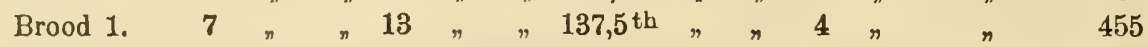

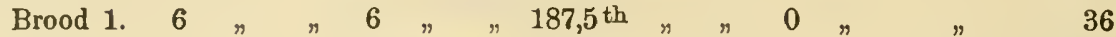

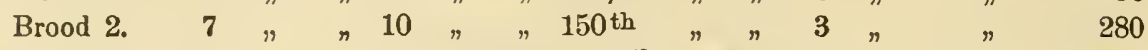

Brood 3. 7 " 79 " 9162,5 th $n$ n 2 n $n$

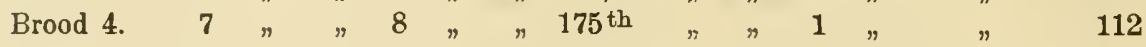

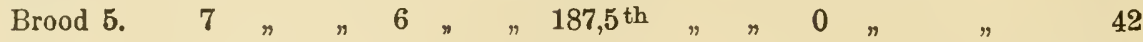

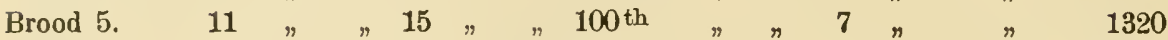

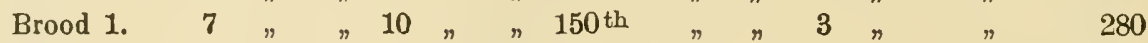

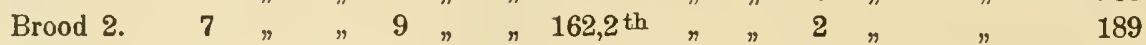

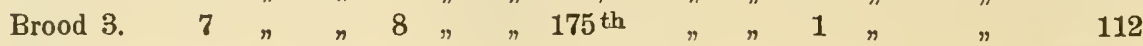

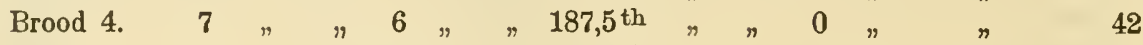

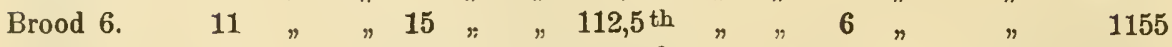

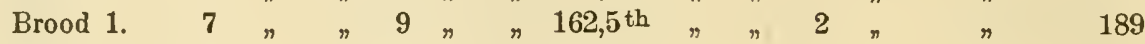

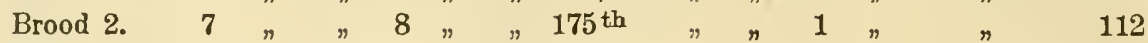

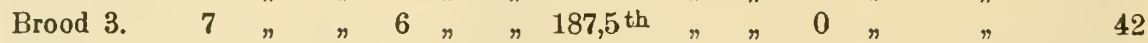

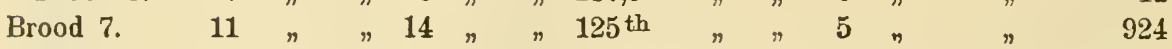

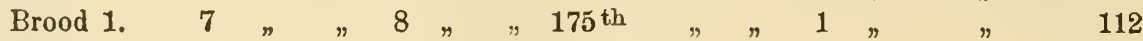

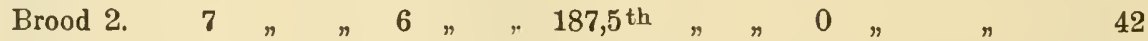

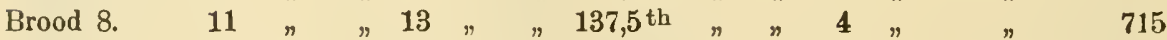

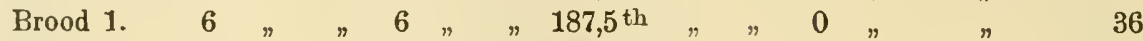

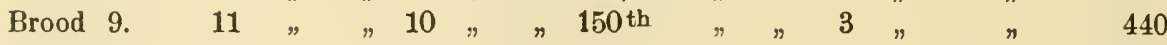

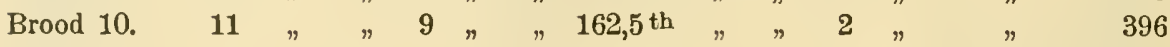

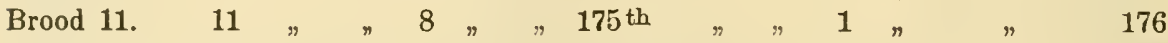

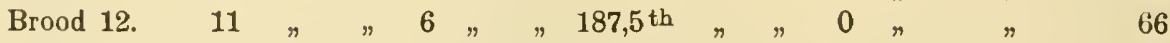

Number of progeny in first generation... 330

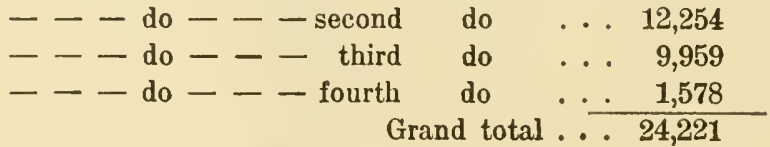

Schedule III. Hyalella.

One pair produces an average of 18 eggs 15 times in 152 days

270

Generation I.

Brood 1. 9 prs. ave., 14 eggs on $43 \mathrm{~d}$ day and 10 times thereafter 1386 Generation II.

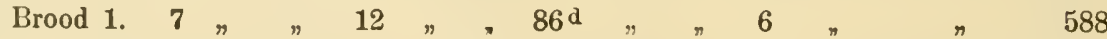

Generation III.

Brood 1. 6 " 10 " $129^{\text {th }} "$ " 2 " 180

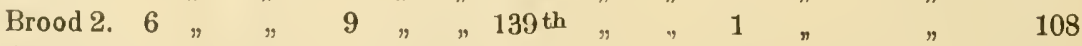

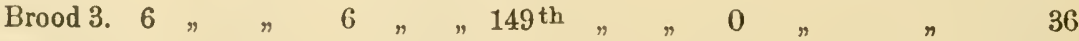

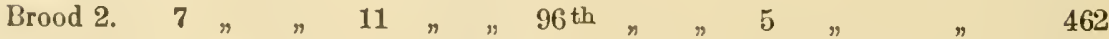

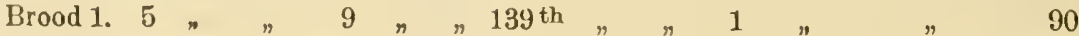

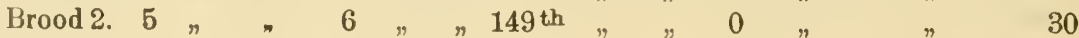


Distribution, Food and reproductive Capacity of some fresh-water Amphipods.

Brood 3. 7 prs. ave,, 11 eggs on $106^{\text {th }}$ day and 4 times thereafter 385

Brood 1. 5 5 " 6 " $149^{\text {th }} "$ " 0 n $n$

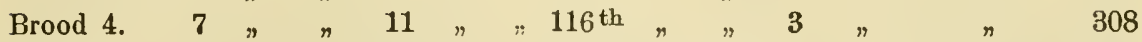

Brood 5. 7 7 $" 10$ n $" 126^{\text {th }} n$ n 2 n $n 210$

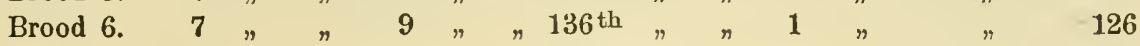

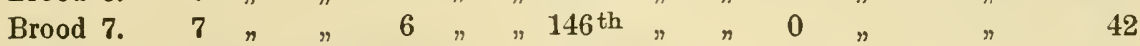

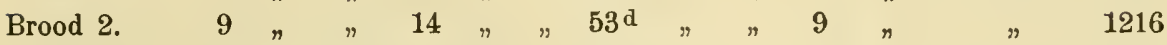

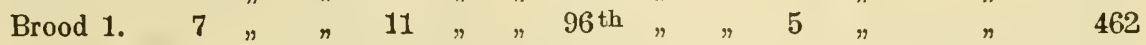

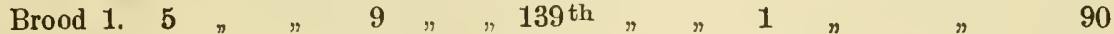

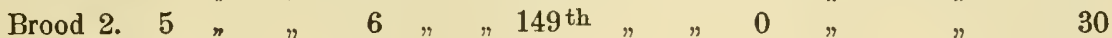

Brood 2. 7 7 11 " 11 106 th, n 4 n $n$

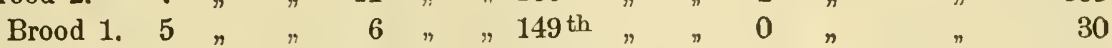

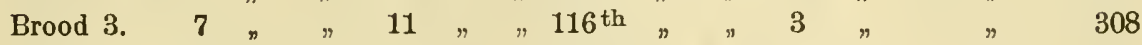

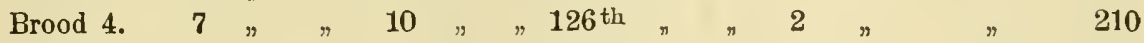

Brood 5. 7 n $" 9$ " $9136^{\text {th }}$, " 1 " $\quad$ " 126

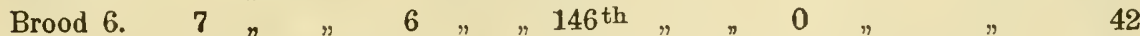

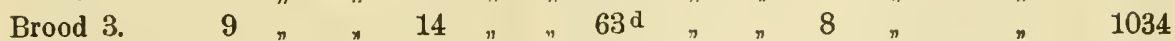

Brood 1. 7 " 11 " 11 106 th $"$ " 4 " 485

Brood 1. 5 " 6 " $6149^{\text {th }}$ ", 00 " 0

Brood 2. 7 " 711 " $116^{\text {th }}$ " 308

Brood 3. 7 " 710 n, $126^{\text {th }}$ " 210

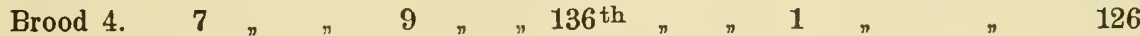

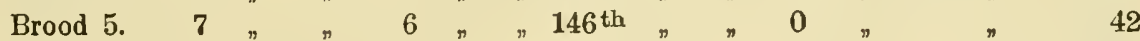

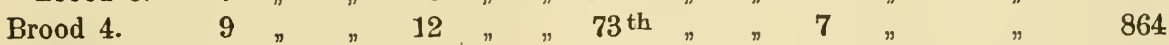

Brood 1. 6 " 11 " $116^{\text {th }}$ ", 3 " 3 " 264

Brood 2. 6 " $" 10$ " $126^{\text {th }}$ " $" 2$ " 2 " 180

Brood 3. 6 " 9 " $9136^{\text {th }} "$ " 1 n . n 108

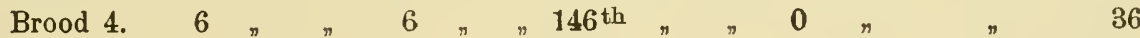

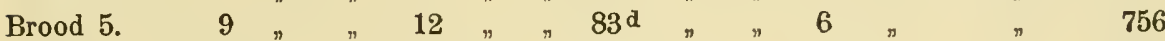

Brood 1. 6 " $" 10$ " 10 126 th "

Brood 2. 6 " $\quad 9$ " $136^{\text {th }} "$ " 1 " 108

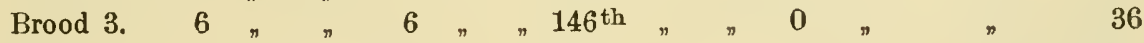

Brood 6. 9 n

Brood 1. 5 " 5 " $9136^{\text {th }}$ " 11 \%

Brood 2. 5 \%

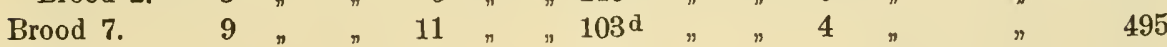

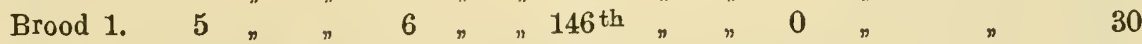

Brood 8. 9 " 11 " $113^{\text {th }}$ ", 3 " 396

Brood 9. 9 " 10 " $10,123^{\mathrm{d}}$ ", 270

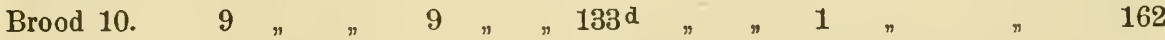

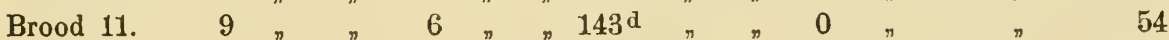

Number of progeny in first generation... 270

- - - do - - second do ... 7,271

- - do - - third do $\ldots 5,781$

- - do - - fourth do ... 654

Grand total 13,976 
G. C. Embody.

\section{Some Enemies of Amphipods.}

The organisms which seem to cause the greatest destruction to amphipods in the waters studied are found among the fishes, birds and aquatic insects.

During each spring thousands of young pike (Esox lucius) are hatched and reared in the Ithaca marshes. Both adults and young were collected during the years 1909 and 1910 and their stomachs examined. There were very fow between the ages of eighteen and fourty-two days (length 24 to $47 \mathrm{~mm}$ ) which had not eaten one or more amphipods. One young pike $36,5 \mathrm{~mm}$, long contained fourteen (six E. gracilis and eight Hyalella) and in the stomach of a third, $44 \mathrm{~mm}$ long, were found ten specimens of E. gracilis. No amphipods were found in pike over $52 \mathrm{~mm}$, in length.

One perch (Perca flavescens) $100 \mathrm{~mm}$, long had eaten seven amphipods (G. fasciatus). The stomachs of many young sun fish (Eupomotis gibbosus) varying in length from 25 to $60 \mathrm{~mm}$, were found to contain from one to six amphipods.

It is common knowledge that the eastern brook trout (Salvelinus fontinalis) feeds upon amphipods and especially upon the so called "Caledonia shrimp", (G. limnaeus). Three young trout approximately $100 \mathrm{~mm}$, long and captured in January had eaten five and seven large "Caledonia shrimps" respectively, notwithstanding the great abundance of Hyalella and E. gracilis in the same stream. Mather (1900, p. 133) states that he believes "Gammarus is greatly overrated as trout food". The stomachs of 247 trout taken from Wilmurt Lake, Herkimer County, New York, were examined by him and were estimated to contain but five percent "Gammarus". The same ratio was found to obtain in 138 stomachs of trout taken from Meacham Lake in the Northern Adirondacks of New York. He further states that a trout of a pound weight seldom eats them.

Among the fishes mentioned by Forbes (1908) as having fed upon amphipods one finds, Notropis heterodon, Schildeodes gyrinus (tadpole cat), Umbra limi (mudfish), Esox vermiculatus (pickerel), Fundulus diaphanus menona, Fundulus notatus, Eupomotis gibbosus, Perca flavescens and Microperca punctulata.

A few instances among the birds have come to the writer's notice. Messrs. A. A. Allen and J. T. Lloyd of Cornell University have found many amphipods in the stomachs of virginia rails (Rallus virginianus) and a fow in those of sora rails (Porzana carolina). In each of two red-wing blackbirds (Agelaius phoeniceus) taken October 15, 
1909, in the Ithaca Marsh, Mr. Allen found a single amphipod. A swamp sparrow (Melospiza georgiana) and a long-billed marsh wren (Telmatodytes palustris), taken in June and July 1909, respectively, each had devoured two Hyalellas. In the stomachs of a spotted sandpiper (Actitis macularia) collected July 15, 1909, fivo amphipods were found.

The most remarkable instance which has come to hand is that of a king eider duck (Somateria spectabilis) captured by Mr. J. T. Lloyd November 26, 1909, in the Montezuma Marshes near the north end of Cayuga Lake. Among other animals, 72 specimens of G. fasciatus were found in its enteron (Embody 1910).

Among the insects, the larva of dytiscid beetles, damsel flies (Lestes) and dragon flies (Anax) have been observed to capture and partially devour amphipods. Many back-swimmers (Notonecta) were seen to pursue, eapture and kill amphipods as large as themselves.

It was thought that Hydras which lived in abundance in vegetation which furnished retreats for amphipods, might capture and devour the young of the latter. Accordingly several Hydras and young amphipods of different ages were placed together in watchglasses. It was demonstrated that young amphipods up to the age of eight days for G. limnaeus and G. fasciatus, and thirteen days for Hyalella, were readily captured and devoured. Young Hyalellas, fifteen days old, readily escaped from the tentacles and seemed not to be affected by the nettle cells. The young of E. gracilis were easily captured and killed as late as the fortieth day.

Bladders of Utricularia which destroy immense numbers of Entomostraca were opened but none was found to contain remains of amphipods. The living plants were placed in aquaria containing amphipods but as far as the writer could determine none of the latter was captured. A young Hyalella was made to enter one of the living bladders. The following day this particular bladder possessed an irregular hole half way to the opening but no amphipod remains. Since Hyalellas were often seen eating the bladders from the outside, it is believed that the hole was made either by the imprisoned Hyalella or by one without. At any rate the original amphipod escaped.

\section{Summary.}

1. In the waters investigated, Gammarus limnaeus and Gammarus fasciatus grow to the greatest size, Eucrangonyx gracilis third and Hyalella knickerbockeri, fourth. 
2. E. gracilis and Hyalella have the widest distribution. They thrive in waters varying widely in temperature, from warm, partially stagnant, marshy pools to the cold, running waters of the trout brook. G. fasciatus seemed to be restricted to Cayuga Lake and its more open tributaries. G. limnaeus is confined to the cold trout brook.

3. All forms were always found associated with vegetation, either living or dead (leaves).

4. The food of the four species is essentially the same and consists of living or dead animals and plants. The former must not be too greatly decomposed. The exuding juices from a freshly killed Asellus seem to attract while those from a Planaria seem to repel amphipods.

5. Hyalellas were found breeding throughout a period of 152 days during a year; E. gracilis, 299 days; G. fasciatus, 199 days, and G. limnaeus 266 days.

6. G. limnaeus ceased breeding in aquarium water when the temperature of the latter approached $18 \mathrm{C}$. The other three species will breed when the temperature is as high as $30 \mathrm{C}$.

7. The males of G. limnaeus, G. fasciatus and Hyalella may mate with females even when the latter carry eggs or young in the brood pouches. According to the writer's observations the males separate permanently from their mates immediately after semination.

8. The average number of eggs deposited at one time by a female $\mathrm{G}$. limnaeus is 25 ; G. fasciatus, 22; E. gracilis, 45; Hyalella, 18.

9. The period of incubation varies inversely as the temperature of the water but not in a constant ratio. It is quite probable that all eggs of $\mathrm{G}$. limnaeus hatch in not less than 18 days after oviposition.

10. The young of E. gracilis when first hatched are smaller and noticably weaker than those of G. limnaeus.

11. The young amphipods remain in the brood pouch during a period varying from 1 to 8 days; but during this time the young of E. gracilis at least, may have left temporarily and voluntarily reentered the pouch several times. ecdysis.

12. The recurrence of oviposition follows closely the recurrence of

13. The period between moults in the case of young amphipods is much shorter than that in the case of adults.

14. In general the period between moults in the case of adults increases as the average mean daily temperature decreases.

15. The young of $\mathrm{E}$. gracilis grow slowly as compared with those of the other three species; probably not reaching sexual maturity until the second year. The young of the other three species mature and reproduce many times during the first year.

16. G. fasciatus has the greatest reproductive capacity followed in order by Hyalella, G. limnaeus and E. gracilis.

17. The important enemies are found among the birds, fishes and insects. Hydras may destroy the young of E. gracilis in considerable numbers. 
Distribution, Food and reproductive Capacity of some fresh-water Amphipods. 33

18. From its large size, rapid growth and greatest reproductive capacity it is evident that G. fasciatus is likely to give the best results if propagated as food for fishes inhabiting the more open, quiet and moderately warm waters.

\section{Bibliography.}

1907. Andrews, E. A., The Young of the Crayfishes Astacus and Cambarus. Smith. Contrib. Knowl., XXXV, pp. 7-79.

1907. Banta, A. M., Fauna of Mayfield's Cave. Carnegie Institution Publication, No. 67.

1904. Cussans, Margaret., Reproduction and Development of Gammarus. Proc. Liverpool Biol. Soc., XVIII, pp. 327-373.

1889. Della, Valle, A., Deposizione, fecondazione. l. c. Segmentazione della uova del Gammarus pulex. Atti. Soc. Nat. Modena, VIII.

1910. Einbody, G. C., Notes on the Food of a King Eider. Science (n. s.), XXXI, p. 630.

1907. Harmon, Mary T., The Relation of the Degree of Injury to the Rate of Regeneration and the Moulting Period of Gammarus. Proc. Ind. Acad. Sci. for 1907, pp. 62-75.

1902. Holmes, S. J., Observations on the Habits of Hyalella dentata, Smith. Science (n. s.), XV, p. 529.

1903. Holmes, S. J., Sex Recognition among Amphipods. Biol. Bull., V., p. 288.

1898. Langenbeck, Clara, Formation of the Germ Layers in the Amphipods Microdeutopus gryllotalpa, Costa. Journ. of Morph. XIV, pp. $301-336$.

1900. Mather, Fred., Modern Fish Culture. New York.

1897. New York State Forest Fish and Game Commission. Report for 1897.

1903. Smallwood, Mabel E., The Beach Flea (Talorchestia Iongicornis). Cold Spring Harbor Monograph No. 1.

1905. Smallwood, Mabel E., The Salt-Marsh Amphipod, Orchestia palustris. Cold Spring Harbor Monograph, III.

1907. Weckel, Ada L., The Fresh-water Amphipods of North America. Proc. U. S. Nat. Mus., Vol. XXXII. 



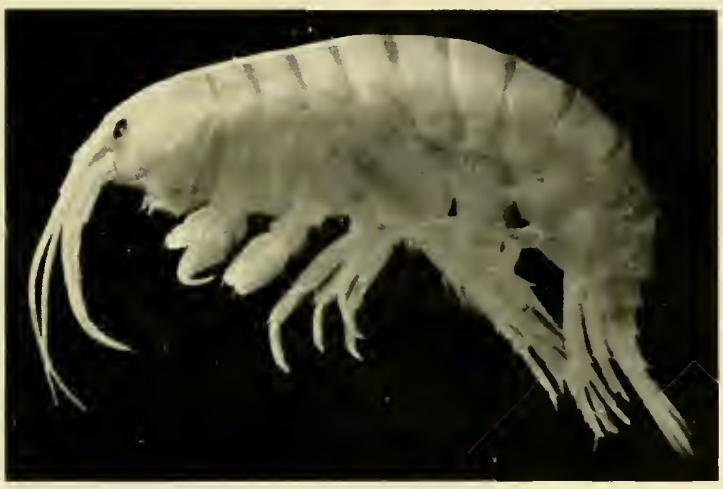

Fig. 1, Gammarus limnaens $(\times 3.5)$.

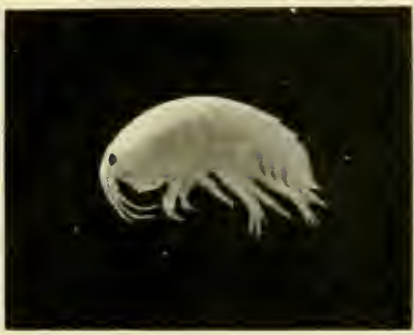

Fig. 4. Hyalella knickerbockeri $(\times 3.5)$.

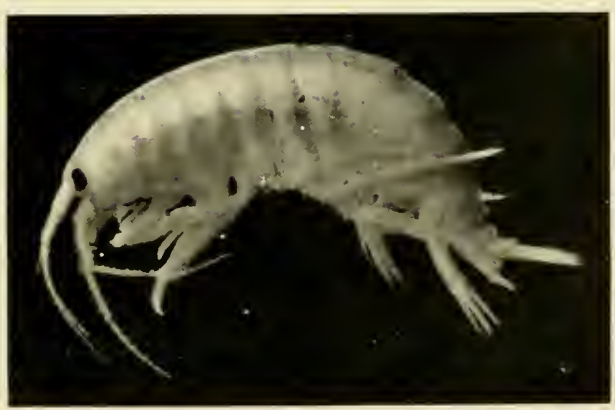

Fig. 2. Gammarus fasciatus $(\times 3,5)$.

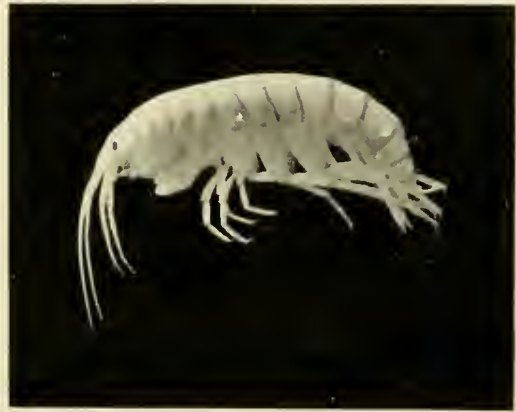

Fig. 3. Encrangonyx gracilis $(\times 3.5)$. 




\section{INTERNATIONALE REVUE \\ DER GESAMTEN \\ HYDROBIOLOGIE UND HYDROGRAPHIE}

Herausgeben von B. HELLAND-HANSEN (Bergen), W. A. HERDMAN (Liverpool), G. KARSTEN (Halle), CH. A. KOFOID (Berkeley), L. MANGIN (Paris), SIR JOHN MURRAY (Edinburgh), A. PENCK (Berlin), E. M. WEDDERBURN (Edinburgh), C. WESENBERG-LUND (Hilleröd), R. WOLTERECK (Leipzig) - $\quad$ und F.ZSCHOKKE (Basel)

Redigiert von Professor R. WOLTERECK (Leipzig)

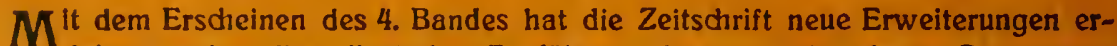
fahren, welche die vollständige Ausfürung des zugrunde gelegten Programms sichern sollen. Ein Stamm von Beratern und Mitarbeitern in allen Teilen der zivilisierten Welt garantiert ferner eine wirkliche Internationalität des Organs, wie sie fär eine wissenschaftliche Zeitschrift von so ausgesprochen synthetischem Charakter notwendig ist.

Das Abonnement kostet pro Band einschlleBlich einer Biologischen oder Hydrographischen Supplement-Serie M. 30. - Jedes weitere Supplement kostet M.10.-

Im Zusammenhang mit der INTERNATIONALEN REVUE erschienen: MONOGRAPHIEN UND ABHANDLUNGEN zur Internat. Revue der gesamten Hydrobiologie und Hydrographie

I. Dr. Adolf Pascher, Chrysomonaden. (Erster Band der naturwissenschaftlichen Untersuchungen aber den Großteich bei Hirschberg in Nordbőhmen.) $4^{0}$. 66 Seiten mit 3 lithographischen Tafeln. Geh. M. 10.-. (Für Abonnenten der Zeitschrift M. 8.-)

II. Dr. OBwald Richter, Die Ernährung der Algen. 40. Iv und 193 Seiten mit 30 Abbild. Geh. M. 12. - . (Für Abonnenten der Zeitschrift M. 9.60) III. Dr. V. H. Langhans, Die Cladoceren. (Zweiter Band der naturwissenschaftilchen Untersuchungen aber den GroBteich bel Hirsciberg in Nordböhmen.) 101 Seiten mit 23 Abbildungen und 16 Kurven- und 39 Kartentafeln. Geh. M. 25.-. (Für Abonnenten der Zeitschrift M. 20.-)

IV. Prof. Dr. F. Zschokke, Die Tiefenfauna der Seen Mitteleuropas. 235 S. m. 1 Karte. Geh. M.15.-. (Für Abonn. der Zeitscirift M.12.-)

VERLAG VON Dr. WERNER KLINKHARDT-IN-LEIPZIG

$\{M+8 \mid j 4,2912 ! 7\}$

